Article

\title{
Scientific Landscape of Smart and Sustainable Cities Literature: A Bibliometric Analysis
}

\author{
Agnieszka Janik $(D$, Adam Ryszko* $*$ and Marek Szafraniec $(\mathbb{D}$ \\ Faculty of Organization and Management, Silesian University of Technology, Roosevelt 32 Str., \\ 41-800 Zabrze, Poland; agnieszka.janik@polsl.pl (A.J.); marek.szafraniec@polsl.pl (M.S.) \\ * Correspondence: adam.ryszko@polsl.pl
}

Received: 21 December 2019; Accepted: 19 January 2020; Published: 21 January 2020

check for updates

\begin{abstract}
The smart sustainable city (SSC) is a concept created in response to problems and challenges arising from rapid urbanization. This is a relatively new term that is developing dynamically, which is confirmed by the growing number of publications over recent years. For this reason, this article presented an up-to-date comprehensive bibliometric analysis to describe and assess the scientific landscape of smart and sustainable cities literature. The analysis was based on two bibliographic sources-the Web of Science Core Collection and the Scopus database. It covers publications on the SSC, as well as documents describing the smart city (SC) and the sustainable city (SuC) concepts separately. VOSviewer and Biblioshiny were selected as software tools for the bibliometric analysis. Based on the descriptive bibliometric analysis, quantity and quality indicators were determined separately for the SC, SuC, and SSC concepts, while the network analysis mapped and covered the level of multi-faceted scientific cooperation in the field of the SSC research. The analysis results were intended to familiarize scholars and practitioners with the most prolific authors, sources, institutions, and countries in the analyzed scientific field, to identify the most influential research channels and impact from authors, sources, countries, and research topics, to determine major clusters of the SSC research and also to provide valuable information for further investigation.
\end{abstract}

Keywords: smart city; sustainable city; smart sustainable city; bibliometric analysis

\section{Introduction}

A city is a place where a large number of people live and work. It is a human settlement, which differs from others not only by its relatively great size but also by its functions entrusted by public administration authorities. According to the United Nations data, the number of city dwellers has increased significantly over the last century. In 2018 , it totaled $55 \%$ of the world's population. It is expected that this percentage will continue to grow (reaching 68\% in 2050), which will be the result of the ongoing gradual relocation of residents from rural to urban areas in parallel with the increase in the overall global population. Almost $90 \%$ of this increase will occur in peripheral countries [1].

People are moving to urban areas, hoping for better education and better job opportunities and seeking a higher standard of living. The growing number of city dwellers creates many problems and challenges that cities now have to face. These problems and challenges include:

- growing demand for land designated for urban development, which results in a reduction in green areas and agricultural land,

- growing environmental threats due to increased air pollution and bigger amounts of liquid and solid waste produced by people living in urban areas,

- $\quad$ increasing demand for resources (water, food, fossil energy resources, etc.) due to the growing needs of urban residents, 
- increasing demand for public services, such as sanitation, public transport, health care, and education,

- growing number of vehicles, causing congestion and traffic jams, as well as greater air pollution,

- increasing the application of new technologies in the development and management of cities, which can improve the living conditions of some city residents, but can also socially exclude those incapable of adopting new solutions.

All these problems and challenges of city life are well-known, and yet people still want to move from rural to urban areas (especially in peripheral countries). In addition, the bigger number of city residents, combined with increased wealth of urban communities, will only aggravate the situation. Therefore, it has become essential to answer the question of how cities should develop and how they should be managed to meet the challenges of urbanization.

Following the sustainable development concept introduced at the end of the 20th century, the concept of sustainable city development was created. According to it, a 'sustainable city' (SuC) is a city organized in a way which 'enables all its citizens to satisfy their own needs and to enhance their well-being without damaging the natural environment or endangering the living conditions of other people, now, or in the future' [2]. Including the principles of sustainable development in the process of designing, building, and managing cities aims to ensure the economic development of cities and to reduce inequalities between citizens, to improve the quality of life and also the quality of the environment [3]. It should be noted that the United Nations Agenda 2030 for the 11th sustainable development goal (SDG 11) recommends making cities more sustainable, resilient, and inclusive [4].

The growing number of urban residents has caused a significant increase in the demand for urban services, which, in many cases, cannot be sufficiently and effectively provided using the existing infrastructure. For this reason, cities began to search for and introduce new intelligent technologies to fulfill their functions better. This resulted in the implementation of the 'smart city' (SC) concept. According to it, a city is smart if it uses clever solutions to thrive and improve the quantity and quality of public services provided to its residents [5,6]. The implementation of new intelligent technologies is considered a key factor in solving urban problems, and for that reason, the United Nations Agenda 2030 in the 9th sustainable development goal (SDG 9) recommends increased application of the information and communication technology (ICT) to build a resilient infrastructure with investments in irrigation, energy generation, and information and communication technologies [4]. However, it should be noted that although the implementation of new technologies can bring many benefits to cities, it can also negatively affect the quality of the environment or the quality of life of inhabitants [7]. It is, therefore, very important to find such innovative solutions and advanced technologies that will allow cities of the 21st century to be both smart and sustainable [8].

The above-mentioned approach has become the pillar of the 'smart sustainable city' (SSC) concept. According to it, the 'smart sustainable city is a city that: (1) meets the needs of its present inhabitants without compromising the ability of other people or future generations to meet their needs, (2) does not exceed environmental limitations in resource sharing and pollution assimilation, and (3) uses new information and communication technologies and advanced technologies to support the tasks entrusted to it' [9]. The concept has mainly developed in ecologically and technologically advanced countries [10], but given the fact that in the coming years the largest increase in urban areas will take place in peripheral countries, it is important that these countries should be able to benefit from the experience of developed countries in creating smart sustainable cities. Unfortunately, the literature and practice present varied definitions and dimensions of the SSC, which makes it difficult to understand the concept unequivocally. For this reason, it is necessary to conduct a thorough analysis to identify the most interesting research directions of the SSC concept development. Although several articles reviewing the literature on the SSC have been published in recent years, they focus primarily on reviewing the SSC definitions and dimensions $[6,10,11]$, trying to find the answer to a research problem defined in relevant articles $[12,13]$ or carrying out a bibliometric analysis in the field of the SC [14-16] or the SuC [17,18], based on a selected single bibliographic database. There are also publications presenting 
the results of a bibliometric analysis carried out in the field of the SSC [19], but they focus on general results from a few years ago, which undoubtedly needs expansion and updating due to the significant increase in the number of the latest SSC publications. Therefore, this paper presented a comprehensive quantitative evaluation of the SSC scientific landscape, based on the development of the SC and the SuC literature, in particular. The detailed and longitudinal bibliometric analysis of the SSC research filled the gap identified in rigorous, systematic, and objective examination of the global patterns and trends of research in this field from multiple perspectives. It was based on two bibliographic sources: the Web of Science (WoS) Core Collection and the Scopus database. Three types of bibliometric indicators were used: quantity indicators (for measuring productivity), quality indicators (for measuring the impact), and structural indicators (for measuring the connections) [20]. A network analysis (i.e., co-keyword analysis, co-authorship analysis, and co-citation analysis) was also performed, and major clusters of the SSC research were identified.

The results achieved in the analyzed domain would enable researchers and practitioners:

- to know the most prolific authors, sources, institutions, and countries in the analyzed scientific field,

- to identify the most influential research channels and impact from authors, sources, countries, and research topics in the SSC literature,

- to determine how the SSC publications are clustered,

- to provide valuable information for further investigation and to determine publication strategies.

The structure of this paper is as follows: Section 2 is an overview of the SC, SuC, and SSC definitions. The research methodology is described in Section 3. Section 4 presents the results and discussion of the bibliometric analysis. Finally, Section 5 offers conclusions and indicates possible directions for future research and limitations.

\section{Towards Smart and Sustainable City-Literature Review}

The SSC concept is derived from the combination of the SC and the SuC. It is conceptually difficult to describe, mainly due to the diversity of definitions of the SC and the SuC. Therefore, to present the essence of the SCC, it is necessary to explain the meaning of the SC and the SuC concepts.

The term 'smart city' (SC) was first used in the early 1990s in connection with the growing significance of new information and communications technologies (ICT's) and modern infrastructures within cities. It has gained greater attention since 2008 due to the launch of the IBM Smarter Planet project [21]. Since then, the concept has evolved, resulting in a variety of SC definitions. Being a multifaceted, wide-ranging, and rather fuzzy notion, it is used in ways that are not always consistent. According to Hall et al. [22], the SC 'monitors and integrates the conditions of all of its critical infrastructures $(\ldots)$, can better optimize its resources, plan its preventive maintenance activities, and monitor security aspects while maximizing services to its citizens'. Giffinger et al. [23] claimed that the SC is 'a city well performing in a forward-looking way in economy, people, governance, mobility, environment, and living, built on the smart combination of endowments and activities of self-decisive, independent, and aware citizens'. Harrison et al. [21] considered the SC as 'an instrumented, interconnected, and intelligent city, connecting the physical infrastructure, the IT infrastructure, the social infrastructure, and the business infrastructure to leverage the collective intelligence of the city'. Kourtit and Nijkamp [24] pointed out that SC is 'the result of knowledge-intensive and creative strategies, aiming at enhancing the socio-economic, ecological, logistic, and competitive performance'. Yigitcanlar et al. indicated that the SC is 'an ideal model to build cities based on a systemic approach, which includes sustainable and knowledge-based development activities to generate desired outcomes and future for all humans and non-humans' $[13,25]$. It seems to be evident that there is no commonly shared definition of the SC. However, there used to be two mainstream approaches to the concept: the approach based on ICT and technology, in general, and the people-oriented approach [26]. Nevertheless, the SC notion technocentricity has been criticized recently [13], and it is emphasized that the development of the SC should be based on a co-creative approach where citizens and other 
stakeholders shape SC services in a collaborative manner [27]. It must be noted that several similar terms are often used interchangeably with the smart city. These include: 'digital cities', 'virtual cities', 'cyber cities', 'networked cities', 'intelligent cities', 'knowledge cities', 'wisdom cities', 'ubiquitous cities', 'real-time cities', and 'hybrid cities', which combine these names [10]. However, these terms refer to more specific aspects of the city [28]. In this way, the SC concept is wider. It often includes the terms [29] and focuses on other issues [30].

The term 'sustainable city' (SuC) also emerged in the early 1990s. As no single definition of 'sustainable development' has been accepted, the SuC does not have one common explanation either. In addition, there are several similar notions often used interchangeably, including sustainable urban, city sustainability, urban sustainability, sustainable urban development, sustainable city development. According to Ewers and Nijkamp [31], the SuC is a city, which has the 'potential to reach qualitatively a new level of socio-economic, demographic, and technological output, which in the long run reinforces the foundations of the urban system'. Girardet [2] claimed that the SuC 'is organized to enable all its citizens to meet their own needs and to enhance their well-being without damaging the natural world or endangering the living conditions of other people, now, or in the future'. The United Nations defines the $\mathrm{SuC}$ as a city, which 'is built on social development, economic development, environmental management, and urban governance to ensure 'low ecological footprint' and eliminate the transfer of economic, social, and environmental hazards to other locations and future generations' [32]. Hiremath et al. [33] described the $\mathrm{SuC}$ as a city that has achieved a balance between urban development and environmental protection. In particular, it is a city that, now and in the future, can satisfy the basic needs of its inhabitants, benefiting all sectors of society [34]. Wang et al. pointed out that the SuC means 'improving the quality of life in a city, including ecological, cultural, political, institutional, social, and economic components without leaving a burden on the future generations' [18]. In general, the SuC integrates environmental, economic, and social considerations to achieve goals of sustainable development. It should provide a safe and healthy urban environment where both people and nature can develop. It must be noted that there are several terms similar to a sustainable city, including, for example, 'eco-cities', 'green cities', or 'resilient cities'. However, these notions refer to more specific aspects of the city, so SuC seems to be a wider, more complex concept.

The 'smart sustainable city' (SSC) is a new phenomenon, and this notion became widespread in the mid-2010s. Being relatively new, the phenomenon has been less explored than the SC and SuC concepts. In general, the SSC is 'a city that is supported by a pervasive presence and massive use of advanced ICT, which, in connection with various urban domains and systems and with how these intricately interrelate, enables cities to become more sustainable and provide citizens with a better quality of life' [35]. Dhingra and Chattopadhyay determined the SSC specific goals expected to be accomplished in an adaptable, reliable, scalable, accessible, and resilient manner [36]. Therefore, the SSC represents and involves 'inherently complex socio-technical systems of all sorts of innovation systems' [35]. In addition, Bibri [37] described the SSC as 'a holistic urban development approach, which seeks to explicitly bring together the sustainable city and the smart city as urban endeavors in ways that address and overcome the key shortcomings of both classes of cities in terms of their contribution to the goals of sustainable development'. The above-mentioned definitions indicate that the field of the SSC is inherently interdisciplinary, comprising technological, social, environmental, economic, cultural, and philosophical perspectives. This is due to the fact that it covers multidimensional issues related to the development of sustainability awareness, rapid urban growth, and technological development. However, research on the SSC is in its early stages, and it needs thorough clarification and operationalization of its characteristics. Nevertheless, the SSC means that SC must contribute to sustainability, including the environmental, economic, and social goals of sustainable development. In this regard, Kramers et al. [38] suggested that the SSC concept should be understood 'as a way of emphasizing initiatives when smartness is (also) used to promote sustainability'. In addition, Höjer and Wangel [9] claimed that the SuC becomes smart when it is supported by ICT. 


\section{Materials and Methods}

The structure of knowledge and the development of research in the fields of smart and sustainable cities were assessed using bibliometric analysis. The analysis covered publications in the SSC field, publications describing the SC concept and the SuC notion separately, as well as publications discussing concepts that some authors connect with $\mathrm{SC}$ or SuC, such as the digital city or the green city. The choice of such a scope of the analysis resulted from the fact that the SC and the SuC concepts had a significant impact on the development of the SSC concept, and, therefore, they had to be included in the in-depth analysis of the scientific landscape of the SSC.

The analysis presented in this article was carried out in the following phases:

Phase 1: Study design;

Phase 2: Data collection;

Phase 3: Initial data analysis;

Phase 4: Descriptive bibliometric analysis;

Phase 5: Network analysis;

Phase 6: Conclusions and directions for future research.

In the first phase of the study, online bibliographic databases were reviewed for the possibility of using them for the research presented in this article. Two bibliographic sources were selected: the Web of Science (WoS) Core Collection and the Scopus database. These databases provide reliable and relevant information on scientific work and are most often selected for bibliometric analyses. All types of scientific papers collected in the WoS and Scopus databases were chosen for the analysis. Then, the bibliometric analysis software tools were reviewed. As the intention was to combine information collected in the WoS and Scopus databases, VOSviewer and Biblioshiny were selected as software tools for the bibliometric analysis. In the next step, a list of the search query words and the Boolean operators were identified. Aiming to conduct an in-depth analysis, the following query words were selected:

- in the extensive scientific field of the SC concept: "smart city/cities", "intelligent city/cities", "digital city/cities", "virtual city/cities" "cyber city/cities", "networked city/cities", "knowledge city/cities", "wisdom city/cities", "ubiquitous city/cities", "real-time city/cities", "hybrid city/cities";

- in the extensive scientific field of the SuC concept: "sustainable city/cities", "sustainable urban", "resilient city/cities", "eco-city/cities", "ecocity/ecocities", "city sustainability", "green city/cities", "urban sustainability", "sustainable urbanization", "sustainable city development", "sustainable urban development";

- in the extensive scientific field of the SSC concept: "smart sustainable city/cities", "sustainable smart city/cities", "smart and sustainable city/cities", "sustainable and smart city/cities", "sustainable and smart urban", "smart and sustainable urban", "sustainable development of smart city/cities", "sustainable development", "sustainability".

The words 'AND' and 'OR' were used as the Boolean operators, resulting in a total of 36 combinations of specific query wording. The lists of query wording instances with relevant Boolean operators are presented in Tables 1-3. In the last step of this phase, the time span of the analysis was determined. Initially, no starting publication date was entered in the search. However, due to the fact that the first publication in the analyzed field (regarding the SuC concept) appeared in 1983, the timespan was narrowed down to 1983-2020.

In the second phase of the study, the analysis input data was collected. The final item of the data was retrieved on 30 October 2019 from the WoS and Scopus databases. Various wording combinations in the publication subject (TS) and the publication title (TI) for the WoS database and in the publication TITLE-ABS-KEY and in the publication TITLE for the Scopus database were used to identify scientific publications in the extensive field of the SC, SuC, and SSC concepts. The obtained results are presented in Tables 1-3. 
Table 1. Results of initial bibliometric analysis of the extensive scientific field of the smart city (SC)—searching by different query wording.

\begin{tabular}{|c|c|c|c|c|c|}
\hline \multirow[b]{2}{*}{ No. } & \multirow[b]{2}{*}{ Query Wording (QW) } & \multicolumn{2}{|c|}{ Web of Science } & \multicolumn{2}{|c|}{ Scopus } \\
\hline & & $\begin{array}{c}\text { QW } \\
\text { Appearance in } \\
\text { Title of } \\
\text { Publication }\end{array}$ & $\begin{array}{c}\text { QW } \\
\text { Appearance as } \\
\text { Topic of } \\
\text { Publication }\end{array}$ & $\begin{array}{c}\text { QW } \\
\text { Appearance in } \\
\text { Title of } \\
\text { Publication }\end{array}$ & $\begin{array}{c}\text { QW } \\
\text { Appearance as } \\
\text { Topic of } \\
\text { Publication }\end{array}$ \\
\hline$\# 1$ & "smart city" OR "smart cities" & 4264 & 9694 & 5976 & 18,695 \\
\hline$\# 2$ & $\begin{array}{c}\text { "intelligent city" OR “intelligent } \\
\text { cities" }\end{array}$ & 70 & 227 & 74 & 295 \\
\hline$\# 3$ & "digital city" OR “digital cities" & 193 & 536 & 268 & 817 \\
\hline$\# 4$ & "virtual city" OR “virtual cities" & 117 & 387 & 172 & 601 \\
\hline \#5 & "cyber city" OR “cyber cities" & 14 & 38 & 21 & 74 \\
\hline \#6 & $\begin{array}{l}\text { "networked city" OR "networked } \\
\text { cities" }\end{array}$ & 44 & 63 & 28 & 58 \\
\hline$\# 7$ & $\begin{array}{c}\text { "knowledge city" OR “knowledge } \\
\text { cities" }\end{array}$ & 104 & 194 & 109 & 234 \\
\hline$\# 8$ & $\begin{array}{l}\text { “wisdom city" OR “wisdom } \\
\text { cities" }\end{array}$ & 10 & 28 & 12 & 34 \\
\hline$\# 9$ & $\begin{array}{c}\text { "ubiquitous city" OR "ubiquitous } \\
\text { cities" }\end{array}$ & 21 & 81 & 32 & 119 \\
\hline$\# 10$ & $\begin{array}{l}\text { "real-time city" OR "real-time } \\
\text { cities" }\end{array}$ & 17 & 40 & 15 & 31 \\
\hline$\# 11$ & "hybrid city" OR “hybrid cities" & 38 & 75 & 55 & 137 \\
\hline $\begin{array}{r}\text { Extens } \\
\# 3 \mathrm{O}\end{array}$ & $\begin{array}{l}\text { re scientific field of SC (\#1 OR \#2 OR } \\
\text { \#4 OR \#5 OR \#6 OR \#7 OR \#8 OR } \\
\text { \#9 OR \#10 OR \#11) }\end{array}$ & 4882 & 11,075 & 6752 & 20,655 \\
\hline $\begin{array}{r}\text { Public } \\
\text { \#3 O }\end{array}$ & $\begin{array}{l}\text { tions indirectly related to SC (\#2 OR } \\
\text { \#4 OR \#5 OR \#6 OR \#7 OR \#8 OR } \\
\text { \#9 OR \#10 OR \#11) }\end{array}$ & 628 & 1603 & 786 & 2309 \\
\hline $\begin{array}{l}\text { Public } \\
\text { by }\end{array}$ & $\begin{array}{l}\text { tions directly related to SC covered } \\
\text { etailed bibliometric analysis (\#1) }\end{array}$ & 4264 & 9694 & 5976 & 18,695 \\
\hline
\end{tabular}

Table 2. Results of initial bibliometric analysis of the extensive scientific field of the sustainable city (SuC)—searching by different query wording.

\begin{tabular}{cccccc}
\hline & & \multicolumn{2}{c}{ Web of Science } & \multicolumn{2}{c}{ Scopus } \\
\cline { 3 - 6 } No. & Query Wording (QW) & $\begin{array}{c}\text { QW } \\
\text { Appearance in } \\
\text { Title of } \\
\text { Publication }\end{array}$ & $\begin{array}{c}\text { QW } \\
\text { Appearance as } \\
\text { Topic of } \\
\text { Publication }\end{array}$ & $\begin{array}{c}\text { QW } \\
\text { Appearance in } \\
\text { Title of } \\
\text { Publication }\end{array}$ & $\begin{array}{c}\text { QW } \\
\text { Appearance as } \\
\text { Topic of } \\
\text { Publication }\end{array}$ \\
\hline$\# 1$ & $\begin{array}{c}\text { "sustainable city" OR } \\
\text { "sustainable cities" }\end{array}$ & 817 & 2161 & 860 & 2678 \\
\hline$\# 2$ & "sustainable urban" & 1448 & 4425 & 1732 & 5980 \\
\hline$\# 3$ & "resilient city" OR "resilient cities" & 169 & 404 & 166 & 461 \\
\hline$\# 4$ & "eco-city" OR "eco-cities" & 241 & 561 & 292 & 647 \\
\hline$\# 5$ & "ecocity" OR "ecocities" & 30 & 71 & 35 & 100 \\
\hline$\# 6$ & "city sustainability" & 30 & 108 & 50 & 211 \\
\hline$\# 7$ & "green city" OR "green cities" & 193 & 427 & 223 & 630 \\
\hline$\# 8$ & "urban sustainability" & 576 & 1910 & 677 & 2326 \\
\hline$\# 9$ & "sustainable urbanization" & 89 & 275 & 101 & 362 \\
\hline$\# 10$ & "sustainable city development" & 21 & 82 & 26 & 109 \\
\hline$\# 11$ & "sustainable urban development" & 377 & 1552 & 467 & 2272 \\
\hline
\end{tabular}


Table 2. Cont.

\begin{tabular}{|c|c|c|c|c|}
\hline \multirow[b]{2}{*}{ Query Wording (QW) } & \multicolumn{2}{|c|}{ Web of Science } & \multicolumn{2}{|c|}{ Scopus } \\
\hline & $\begin{array}{c}\text { QW } \\
\text { Appearance in } \\
\text { Title of } \\
\text { Publication }\end{array}$ & $\begin{array}{c}\text { QW } \\
\text { Appearance as } \\
\text { Topic of } \\
\text { Publication }\end{array}$ & $\begin{array}{c}\text { QW } \\
\text { Appearance in } \\
\text { Title of } \\
\text { Publication }\end{array}$ & $\begin{array}{c}\text { QW } \\
\text { Appearance as } \\
\text { Topic of } \\
\text { Publication }\end{array}$ \\
\hline $\begin{array}{c}\text { Extensive scientific field of SuC (\#1 OR \#2 OR } \\
\text { \#3 OR \#4 OR \#5 OR \#6 OR \#7 OR \#8 OR \#9 OR } \\
\text { \#10 OR \#11) }\end{array}$ & 3554 & 9249 & 4094 & 11,990 \\
\hline $\begin{array}{c}\text { Publications indirectly related to SuC (\#2 OR } \\
\text { \#3 OR \#4 OR \#5 OR \#6 OR \#7 OR \#8 OR \#9 OR } \\
\text { \#10 OR \#11) }\end{array}$ & 2770 & 7638 & 3274 & 10,034 \\
\hline $\begin{array}{l}\text { Publications directly related to SuC covered } \\
\text { by detailed bibliometric analysis (\#1) }\end{array}$ & 817 & 2161 & 860 & 2678 \\
\hline
\end{tabular}

Table 3. Results of initial bibliometric analysis of the extensive scientific field of the smart sustainable city (SSC)—searching by different query wording.

\begin{tabular}{|c|c|c|c|c|c|}
\hline \multirow[b]{2}{*}{ No. } & \multirow[b]{2}{*}{ Query Wording (QW) } & \multicolumn{2}{|c|}{ Web of Science } & \multicolumn{2}{|c|}{ Scopus } \\
\hline & & $\begin{array}{c}\text { QW } \\
\text { Appearance in } \\
\text { Title of } \\
\text { Publication }\end{array}$ & $\begin{array}{c}\text { QW } \\
\text { Appearance as } \\
\text { Topic of } \\
\text { Publication }\end{array}$ & $\begin{array}{c}\text { QW } \\
\text { Appearance in } \\
\text { Title of } \\
\text { Publication }\end{array}$ & $\begin{array}{c}\text { QW } \\
\text { Appearance as } \\
\text { Topic of } \\
\text { Publication }\end{array}$ \\
\hline$\# 1$ & $\begin{array}{l}\text { "smart sustainable city" OR } \\
\text { "smart sustainable cities" }\end{array}$ & 38 & 64 & 57 & 108 \\
\hline$\# 2$ & $\begin{array}{l}\text { "sustainable smart city" OR } \\
\text { "sustainable smart cities" }\end{array}$ & 33 & 63 & 41 & 83 \\
\hline \#3 & $\begin{array}{l}\text { "smart and sustainable city" OR } \\
\text { "smart and sustainable cities" }\end{array}$ & 23 & 51 & 27 & 66 \\
\hline$\# 4$ & $\begin{array}{l}\text { "sustainable and smart city" OR } \\
\text { "sustainable and smart cities" }\end{array}$ & 3 & 11 & 3 & 16 \\
\hline$\# 5$ & $\begin{array}{l}\text { "sustainable city" AND "smart } \\
\text { city" OR "sustainable cities" AND } \\
\text { "smart cities" }\end{array}$ & 7 & 159 & 11 & 265 \\
\hline \#6 & $\begin{array}{l}\text { "sustainable and smart urban" OR } \\
\text { "smart and sustainable urban" }\end{array}$ & 7 & 17 & 8 & 21 \\
\hline$\# 7$ & $\begin{array}{l}\text { "sustainable development of } \\
\text { smart city" OR "sustainable } \\
\text { development of smart cities" }\end{array}$ & 2 & 14 & 3 & 16 \\
\hline$\# 8$ & $\begin{array}{l}\text { "sustainable development" AND } \\
\text { "smart city" OR “sustainable } \\
\text { development" AND "smart cities" }\end{array}$ & 17 & 310 & 23 & 1031 \\
\hline$\# 9$ & $\begin{array}{c}\text { "sustainability" AND “smart city" } \\
\text { OR "sustainability" AND } \\
\text { "smart cities" }\end{array}$ & 39 & 731 & 48 & 998 \\
\hline $\begin{array}{l}\text { Exte } \\
\# 2 \mathrm{O}\end{array}$ & $\begin{array}{l}\text { sive scientific field of SSC (\#1 OR } \\
\text { \#3 OR \#4 OR \#5 OR \#6 OR \#7 OR } \\
\text { \#8 OR \#9 OR) }\end{array}$ & 165 & 1117 & 215 & 1804 \\
\hline \multicolumn{2}{|c|}{$\begin{array}{l}\text { Publications directly related to SSC covered } \\
\text { by detailed bibliometric analysis }\end{array}$} & \multicolumn{2}{|c|}{355} & \multicolumn{2}{|c|}{489} \\
\hline \multicolumn{2}{|c|}{$\begin{array}{l}\text { The final number of publications on SSC } \\
\text { covered by the network analysis }\end{array}$} & \multicolumn{4}{|c|}{539} \\
\hline
\end{tabular}

The third phase of the study consisted of a preliminary review of the collected data. This was limited to the records directly related to the SC and the SuC. In the next step, the publications included in the identified extensive scientific field of the SSC were screened (i.e., titles and abstracts) to indicate the items directly related to the SSC concept. In addition, the papers defining the SC, SuC, and SSC 
concepts were selected to show the development of individual concepts and their impact on the development of the SSC concept (this is presented in Section 2).

The database created in this way became the basis for descriptive bibliometric analysis (the fourth phase of the study). The analysis was carried out separately for scientific papers, describing the concepts of the SC, the SuC, and the SSC. For each of these concepts, the number of publications and the total number of citations, the main research areas and research categories, the most productive authors, sources, countries, and organizations publishing scientific works were determined. The decision to conduct a separate descriptive analysis for each concept resulted from the fact that the concepts appeared in different years, which affects the number of published articles or the number of citations and makes it difficult to perform a joint analysis of all data.

In the fifth phase of the study, a network analysis was performed. To achieve the purpose of the article, a decision was made to perform the network analysis for the SSC concept data collected from the WoS and Scopus databases. This analysis was conducted using the VOSviewer (version 1.6.11) (Centre for Science and Technology Studies, Leiden University, The Netherlands, 2019) and Biblioshiny (based on R version 3.6.1, Bibliometrix package version 2.2.1)(University of Naples Federico II, Naples, Italy, 2016) software tools. VOSviewer is powerful at showing networks of structures composed of many elements based on a distance-based visualization approach. The created networks consist of nodes and lines. Depending on the subject of the analysis, the nodes are represented, e.g., by keywords, sources, countries, or authors. The nodes are grouped into clusters (i.e., each node is assigned to exactly one cluster). The lines represent the relationships between them, e.g., co-occurrence, co-citation. The number of obtained clusters can be determined (limited) by a clustering parameter (e.g., cluster minimum size). However, to achieve the highest homogeneity of individual clusters, this was not the case in the performed analyses. The clustering technique used by the VOSviewer is discussed by Waltman, Van Eck, and Noyons [39]. The technique requires a relevant algorithm for solving an optimization problem. For this purpose, VOSviewer uses the smart local moving algorithm introduced by Waltman and Van Eck [40]. Biblioshiny is a proper tool for presenting general statistics and relations between the most important scientific collaboration units, using the Three Fields Plot [41]. In the first step of this phase, the data obtained from the two databases were converted into an appropriate format, which could be processed using the selected software tool. This made it possible to create a common database. Then, the data was cleaned by removing duplicates and misspelled elements. This enabled the determination of the final number of publications covered by the network analysis (539 items). The network analysis was divided into three parts: (1) Word, keyword, and co-keyword analyses; (2) Scientific collaboration mapping; (3) Top authors, sources, and keywords relations. Word, keyword, and co-keyword analyses are methods of describing and visualizing the structure of scientific fields of a particular group of publications [42]. The level of scientific collaboration is measured, among others, by citation and co-citation analyses [41]. Therefore, scientific collaboration was mapped and analyzed using the results of the co-authorship network of countries and the citation network of authors, countries, and sources. Top authors, sources, and keywords relations were developed using the Three Fields Plot of the Biblioshiny package. The tool makes it possible to visualize the main items of three selected fields (e.g., authors, authors' keywords, sources) and show how they are related using a Sankey diagram. As for the network analysis, it was assumed that the networks would contain a maximum range of information. Therefore, the boundary conditions were always set to the minimum (1 occurrence/citation). Only in the network of keywords' co-occurrence, was the threshold set to 3 (occurrences) to make the network legible and draw attention to the most significant elements, relations, and structures thereof.

The final phase of the study included the presentation of conclusions on academic trends and directions for future research in the SSC field.

All the phases of the study presented in this article are shown in Figure 1. 
Phase 1: Study design

1.1. Selection of databases with bibliometric data:

the WoS and Scopus

1.2. Selection of software tools for analysis:

VOSviewer and Biblioshiny

1.3. Selection of query wording and boolean operators: combinations presented in Table 1, Table 2 and Table 3

1.4. Selection of timespan: 1983-2020

Phase 2: Data collection

2.1. Data collection on publications in the field of SC literature:

11075 publications in the WoS and 20655 publications in Scopus

2.2. Data collection on publications in the field of SuC literature:

9249 publications in the WoS and 11990 publications in Scopus

2.3. Data collection on publications in the field of SSC literature: 1117 publications in the WoS and 1804 publications in Scopus

Phase 3: Initial data analysis

3.1. Determination of publications directly related to:

SC : 9694 in the WoS and 18695 in Scopus

SuC: 2161 in the WoS and 2678 in Scopus

SSC: 355 in the WoS and 489 in Scopus

3.2. Identification of publications describing definitions of SC, SuC and SSC

Phase 4: Descriptive bibliometric analysis

4.1. Descriptive bibliometric analysis of $S C$ research:

the number of publications and total citations, the main research areas and categories of studies, the most productive authors, sources, countries and organizations

4.2. Descriptive bibliometric analysis of $\mathrm{SuC}$ research:

the number of publications and total citations, the main research areas and categories of studies, the most productive authors, sources, countries and organizations

4.3. Descriptive bibliometric analysis of SSC research:

the number of publications and total citations, the main research areas and categories of studies, the most productive authors, sources, countries and organizations

Phase 5: Network analysis of the SSC research

5.1. Converting data from the WoS and Scopus databases to appropriate format for the bibliometric tools used in the study

5.2. Merging of data from the WoS and Scopus databases

5.3. Data reduction:

exclusion of duplicates and misspelled elements - the final number of publications covered by the network analysis - 539 items

5.4. Keywords and co-keywords analysis:

most frequently used words, author keywords dynamics, co-occurrence, network of authors' keywords

5.5. Mapping the scientific collaboration: co-authorship network of countries, citation network of authors, citation network of countries, citation network of sources

5.6. Top authors, sources and keywords relations:

relations between author keywords, authors and sources, relations between author keywords, sources and cited sources in the literature field

Phase 6: Conclusions and directions for future research

Figure 1. Research methodology. 


\section{Results and Discussion}

\subsection{Descriptive Bibliometric Analysis of the SC Publications}

The analysis resulted in 11,075 and 20,655 publications indexed in the WoS and the Scopus database, respectively, covering the extensive scientific field of the SC (Table 1). The detailed analysis that followed was focused on publications directly related to the SC, i.e., publications where the term 'smart city' or 'smart cities' appeared as the topic or part of the title. The above-mentioned query wording was revealed as the publication topic in 9694 records listed in the WoS database (including three main document types: 5107 proceedings papers, 4081 articles, and 498 book chapters) and 18,695 records indexed in the Scopus database (including 11,910 proceedings papers, 4697 articles, and 800 book chapters). Considering the analyzed query wording in the publication title, there were 4264 such publications indexed in the WoS database (including 2130 proceedings papers, 1762 articles, and 321 book chapters) and 5976 publications listed in the Scopus database (including 3058 proceedings papers, 2023 articles, and 415 book chapters).

Table 4 presents indicators of publication activity related to the SC concept based on records included in the WoS and Scopus databases. It covers the number of publications (i.e., annual and cumulative) for the period of 1991-2020 and the number of citations that these items have received. The data indicated that from 2010 to 2019, the number of publications on the SC and of relevant citations increased considerably.

Table 4. The number of publications and total citations related to the SC literature.

\begin{tabular}{|c|c|c|c|c|c|c|}
\hline \multirow[b]{2}{*}{ Year } & \multicolumn{3}{|c|}{ Web of Science } & \multicolumn{3}{|c|}{ Scopus } \\
\hline & $\begin{array}{c}\text { Number of } \\
\text { Publications }\end{array}$ & $\begin{array}{l}\text { Cumulative Number } \\
\text { of Publications }\end{array}$ & $\begin{array}{c}\text { Total } \\
\text { Citations }\end{array}$ & $\begin{array}{c}\text { Number of } \\
\text { Publications }\end{array}$ & $\begin{array}{c}\text { Cumulative Number } \\
\text { of Publications }\end{array}$ & $\begin{array}{c}\text { Total } \\
\text { Citations }\end{array}$ \\
\hline 1991 & 1 & 1 & 0 & 0 & 0 & 0 \\
\hline 1992 & 0 & 1 & 0 & 0 & 0 & 0 \\
\hline 1993 & 1 & 2 & 0 & 0 & 0 & 0 \\
\hline 1994 & 0 & 2 & 3 & 0 & 0 & 0 \\
\hline 1995 & 0 & 2 & 6 & 0 & 0 & 0 \\
\hline 1996 & 0 & 2 & 1 & 0 & 0 & 0 \\
\hline 1997 & 0 & 2 & 0 & 1 & 1 & 0 \\
\hline 1998 & 0 & 2 & 0 & 1 & 2 & 0 \\
\hline 1999 & 4 & 6 & 0 & 4 & 6 & 1 \\
\hline 2000 & 1 & 7 & 0 & 18 & 24 & 8 \\
\hline 2001 & 1 & 8 & 0 & 0 & 24 & 8 \\
\hline 2002 & 1 & 9 & 1 & 2 & 26 & 11 \\
\hline 2003 & 0 & 9 & 1 & 2 & 28 & 5 \\
\hline 2004 & 1 & 10 & 0 & 1 & 29 & 18 \\
\hline 2005 & 0 & 10 & 1 & 1 & 30 & 16 \\
\hline 2006 & 3 & 13 & 0 & 3 & 33 & 13 \\
\hline 2007 & 1 & 14 & 2 & 1 & 34 & 10 \\
\hline 2008 & 3 & 17 & 6 & 6 & 40 & 28 \\
\hline 2009 & 8 & 25 & 19 & 18 & 58 & 35 \\
\hline 2010 & 15 & 40 & 22 & 36 & 94 & 44 \\
\hline 2011 & 48 & 88 & 36 & 124 & 218 & 137 \\
\hline 2012 & 90 & 178 & 89 & 217 & 435 & 317 \\
\hline 2013 & 271 & 449 & 248 & 486 & 921 & 884 \\
\hline 2014 & 527 & 976 & 897 & 797 & 1718 & 2261 \\
\hline 2015 & 1046 & 2022 & 2364 & 1187 & 2905 & 4690 \\
\hline 2016 & 1611 & 3633 & 4735 & 1931 & 4836 & 8556 \\
\hline 2017 & 2289 & 5922 & 9260 & 4190 & 9026 & 15,194 \\
\hline 2018 & 2316 & 8238 & 14,946 & 5307 & 14,333 & 27,792 \\
\hline 2019 & 1450 & 9688 & 16,979 & 4236 & 18,569 & 34,094 \\
\hline 2020 & 6 & 9694 & 78 & 126 & 18,695 & 1162 \\
\hline
\end{tabular}

The search for the term 'smart city' or 'smart cities' in the WoS and the Scopus database returned the first reference to it in 1991 [43] and in 1997 [44], respectively. 
The most cited article on the SC in the WoS database, with 1425 citations, was 'Internet of things for smart cities' written by Zanella et al. [45]. In the second place was 'Smart cities in Europe' written by Caragliu et al. [5], cited 722 times. The study by Botta et al. [46] 'Integration of cloud computing and internet of things: A survey' appeared in third place with 509 citations. The most cited publication on the SC in the Scopus database, with 2264 citations, was 'Fog computing and its role in the internet of things' [47]. Interestingly enough, this paper was not indexed in the WoS database. In the second place in the Scopus database was 'Internet of things for smart cities' [45], with 1917 citations. 'Smart cities in Europe' [5] took third place with 913 citations. Tables A1 and A2 in Appendix A show the most cited publications on the SC in the WoS and Scopus databases. It should be noted that most studies on the lists with the highest number of citations were from the period of 2011-2016.

In the next step, the main research areas and categories of studies on the SC were identified, together with sources and authors with the most substantive contributions to the literature. Moreover, the most productive countries and organizations in the field were indicated. The analysis results showed that:

- Studies on SC covered diverse research areas. According to the WoS database, these areas included, in particular, Computer Science ( 4615 records with $47.6 \%$ of all publications on the SC), Engineering (3970, 41\%), and Telecommunications (1969, 20.3\%). Considering the WoS categories, the most popular were Engineering Electrical and Electronic (3334 records in the WoS database with $34.4 \%$ of all publications on the SC), Computer Science Information Systems (2062, 21.3\%), and Telecommunications (1995, 20.6\%). Moreover, the SC publications covered the following subject areas in the Scopus database: Computer Science (13,385 records with $71.6 \%$ of all publications on the SC indexed in the Scopus database), Engineering $(7306,39.1 \%)$, and Social Sciences $(4678,25 \%)$.

- Most publications on the SC indexed in the WoS database appeared in IEEE Access (228 items), Sensors (222), and Lecture Notes in Computer Science (216). The most popular Scopus-indexed sources were Lecture Notes in Computer Science (653), ACM International Conference Proceeding Series (562), and HPCC/SmartCity/DSS 2019 Proceedings (383).

- The most prolific authors with the most frequent contributions to the SC literature in the WoS database were Neera Kumar (28 publications), Burak Kantarci (25), and Enrique Alba (24). The top of the list of the most productive authors on the SC in the Scopus database was as follows: Paolo Nesi (34), Enrique Alba (32), and Schahram Dustdar (29).

- The most productive countries in the SC literature field indexed in the WoS database were China (1269 WoS-indexed publications), the United States (1264), and Italy (1175). According to the Scopus database, the order of the most prolific countries was as follows: China (3613 Scopus-indexed records), the United States (2254), and India (1740).

- The most active organizations with regard to SC publications indexed in the WoS database were the Chinese Academy of Sciences (103 WoS-indexed publications), the University of Bologna (96), and the Polytechnic University of Milan (95). Most SC publications indexed in the Scopus database were affiliated to the Moscow State University of Civil Engineering (194), the Chinese Academy of Sciences (187), and the Polytechnic University of Milan (131).

The most productive authors, sources, countries, and organizations in the SC literature field are presented in Tables A3 and A4 in Appendix A.

\subsection{Descriptive Bibliometric Analysis of the SuC Publications}

The analysis revealed 9249 and 11,990 records listed in the WoS and the Scopus database, respectively, covering the extensive scientific field of the SuC (Table 2). The detailed analysis that followed concerned publications directly related to the $\mathrm{SuC}$, i.e., publications where the term 'sustainable city' or 'sustainable cities' appeared as the publication topic or part of the title. The above-mentioned query wording appeared as the topic of 2161 publications (including three main document types: 1254 articles, 611 proceedings papers, and 164 book chapters) and in the title of 817 records (including 
353 articles, 212 proceedings papers, and 108 book chapters) indexed in the WoS database. This wording also appeared as the topic of 2678 publications (including 1573 articles, 526 proceedings papers, and 269 book chapters) and in the title of 860 items indexed in the Scopus database (including 435 articles, 177 proceedings papers, and 121 book chapters).

Table 5 presents indicators of publication activity related to the SuC literature based on the items indexed in the WoS and Scopus databases. It contains the number of publications (i.e., annual and cumulative) for the period of 1983-2020 and the number of citations that these items have received.

Table 5. The number of publications and total citations related to the SuC literature.

\begin{tabular}{|c|c|c|c|c|c|c|}
\hline \multirow[b]{2}{*}{ Year } & \multicolumn{3}{|c|}{ Web of Science } & \multicolumn{3}{|c|}{ Scopus } \\
\hline & $\begin{array}{l}\text { Number of } \\
\text { Publications }\end{array}$ & $\begin{array}{c}\text { Cumulative Number } \\
\text { of Publications }\end{array}$ & $\begin{array}{c}\text { Total } \\
\text { Citations }\end{array}$ & $\begin{array}{c}\text { Number of } \\
\text { Publications }\end{array}$ & $\begin{array}{l}\text { Cumulative Number } \\
\text { of Publications }\end{array}$ & $\begin{array}{c}\text { Total } \\
\text { Citations }\end{array}$ \\
\hline 1983 & 0 & 0 & 0 & 1 & 1 & 0 \\
\hline 1991 & 1 & 1 & 0 & 2 & 3 & 0 \\
\hline 1992 & 9 & 10 & 0 & 4 & 7 & 2 \\
\hline 1993 & 1 & 11 & 0 & 5 & 12 & 1 \\
\hline 1994 & 7 & 18 & 0 & 9 & 21 & 7 \\
\hline 1995 & 13 & 31 & 0 & 10 & 31 & 10 \\
\hline 1996 & 13 & 44 & 1 & 25 & 56 & 18 \\
\hline 1997 & 16 & 60 & 9 & 12 & 68 & 24 \\
\hline 1998 & 21 & 81 & 11 & 21 & 89 & 47 \\
\hline 1999 & 21 & 102 & 24 & 20 & 109 & 60 \\
\hline 2000 & 18 & 120 & 19 & 31 & 140 & 55 \\
\hline 2001 & 15 & 135 & 29 & 14 & 154 & 68 \\
\hline 2002 & 29 & 164 & 42 & 34 & 188 & 104 \\
\hline 2003 & 28 & 192 & 40 & 22 & 210 & 98 \\
\hline 2004 & 31 & 223 & 61 & 33 & 243 & 124 \\
\hline 2005 & 32 & 255 & 87 & 29 & 272 & 161 \\
\hline 2006 & 35 & 290 & 128 & 61 & 333 & 238 \\
\hline 2007 & 36 & 326 & 188 & 60 & 393 & 292 \\
\hline 2008 & 32 & 358 & 218 & 64 & 457 & 419 \\
\hline 2009 & 41 & 399 & 308 & 60 & 517 & 529 \\
\hline 2010 & 72 & 471 & 425 & 99 & 616 & 643 \\
\hline 2011 & 101 & 572 & 561 & 154 & 770 & 855 \\
\hline 2012 & 89 & 661 & 724 & 132 & 902 & 1151 \\
\hline 2013 & 105 & 766 & 944 & 161 & 1063 & 1523 \\
\hline 2014 & 113 & 879 & 1303 & 192 & 1255 & 1886 \\
\hline 2015 & 166 & 1045 & 1687 & 182 & 1437 & 2248 \\
\hline 2016 & 242 & 1287 & 2193 & 207 & 1644 & 2670 \\
\hline 2017 & 306 & 1593 & 2994 & 300 & 1944 & 3867 \\
\hline 2018 & 320 & 1913 & 3979 & 378 & 2322 & 5140 \\
\hline 2019 & 247 & 2160 & 4286 & 326 & 2648 & 5773 \\
\hline 2020 & 1 & 2161 & 13 & 30 & 2678 & 209 \\
\hline
\end{tabular}

The first reference to the SuC concept, recognizing the need for sustainable cities, was indexed in the Scopus and the WoS database in 1983 [48] and 1991 [49], respectively.

The most cited article on the SuC, indexed in the WoS and Scopus databases, was 'The role of urban parks for the sustainable city' by Chiesura [50] (with 830 citations in the WoS and 945 citations in the Scopus database). The study by Kennedy et al. [51] titled 'The changing metabolism of cities' was in second place in the WoS (cited 522 times) and in the third place in the Scopus database (577 citations). The second-place Scopus-indexed item was 'Urbanization in developing countries: Current trends, future projections, and key challenges for sustainability' by Cohen [52] (636 citations). Interestingly enough, this paper was not indexed in the WoS database. The article 'Rethinking sustainable cities: Multilevel governance and the 'urban' politics of climate change' by Bulkeley and Betsill [53] ranked third in the WoS database with 446 citations. Tables A5 and A6 in Appendix A show the most cited publications on the SuC in the WoS and Scopus databases. It should be added that most studies on the lists with the highest number of citations were from the period of 2004-2007. 
The analysis of the main research areas and categories of studies on the SuC, including the most productive sources, authors, countries, and organizations in the field, indicated that:

- Studies on the SuC covered diverse research areas. In the WoS database, the areas included, in particular, Environmental Sciences and Ecology (819 records with $37.9 \%$ of all publications), Urban Studies (561, 26\%), and Science Technology other topics (492, 22.8\%). The most popular were the following WoS-indexed categories: Urban Studies (561, 26\%), Environmental Studies (491, 22.7\%), and Environmental Sciences (490, 22.7\%). In addition, the SuC publications indexed in the Scopus database primarily concerned the following subject areas: Social Sciences (1307, 48.8\%), Environmental Science (1068, 39.9\%), and Engineering (751, 28\%).

- The most popular WoS-indexed sources of publications on the SuC were Sustainability (107 records), Sustainable Cities and Society (66), and WIT Transactions on Ecology and the Environment (63). Most SuC publications indexed in the Scopus database appeared in WIT Transactions on Ecology and the Environment (111), Sustainability (105), and Sustainable Cities and Society (71).

- The most productive authors in the literature on the SuC in the WoS database were Kent E. Portney (24 publications), Sheldon Kamieniecki (15), and Michael E. Kraft (15). The top of the list of the most prolific authors on the SuC in the Scopus database was as follows: Simon Elias Bibri (24), Peter Nijkamp (11), Kent E. Portney (10), and Tan Yigitcanlar (10).

- The most active countries in the SuC literature field, according to the WoS database, were the United States (324 publications), the United Kingdom (216), and China (188). The order of the most productive countries in this field, as indicated by the Scopus database, was as follows: the United States (383), the United Kingdom (297), and Australia (189).

- The most prolific organizations with regard to the SuC publications indexed in the WoS database were the University of London (39 records), the Royal Institute of Technology (31), and the University of California (28). According to the Scopus database, the most active were the University of Melbourne (33), the Royal Institute of Technology (32), and University College London (32).

The most productive authors, sources, countries, and organizations in the SuC literature field are presented in Tables A7 and A8 in Appendix A.

\subsection{Descriptive Bibliometric Analysis of the SSC Publications}

The analysis indicated 1117 and 1804 publications listed in the WoS and the Scopus database, respectively, covering the extensive scientific field of the SSC (Table 3). The items (i.e., titles and abstracts) were screened to determine publications directly related to the SSC concept. The process resulted in 355 publications (including 195 articles, 116 proceedings papers, and 29 book chapters) indexed in the WoS database and 489 Scopus-indexed items (including 239 articles, 167 proceedings papers, and 49 book chapters).

Table 6 presents indicators of publication activity related to the SSC literature based on items indexed in the WoS and Scopus databases. It contains the number of publications (i.e., annual and cumulative) for the period of 2005-2020 and the number of citations that these items have received.

The first-ever publication on the SSC, indexed in the WoS and Scopus databases, was a book chapter titled 'Smart and sustainable city—a case study from Hong Kong' by Lau et al. [54]. It was published in June 2005, which was correctly recorded in the WoS database. According to the Scopus database, the publication was from 2008.

The most cited article on the SSC recorded in the WoS and the Scopus database (with 163 and 217 citations, respectively) was the paper by Lee et al. [55] titled 'Towards an effective framework for building smart cities: Lessons from Seoul and San Francisco'. The study 'Smart and digital city: A systematic literature review' by Cocchia [14] appeared in second place in the WoS database with 160 citations. Interestingly enough, this publication was not indexed in the Scopus database. The article 'Sustainable-smart-resilient-low carbon-eco-knowledge cities: Making sense of a multitude of concepts promoting sustainable urbanization' by De Jong et al. [56] ranked third in the WoS database 
(158 citations) and second in the Scopus database (205 citations). In the third place in the Scopus database was the study 'Programming environments: Environmentality and citizen sensing in the smart city' by Gabrys [57] (180 citations). Tables A9 and A10 in Appendix A show the most cited publications on the SSC in the WoS and Scopus databases. It should be added that most studies on the lists with the highest number of citations were from the period of 2014-2017.

Table 6. The number of publications and total citations related to the SSC literature.

\begin{tabular}{|c|c|c|c|c|c|c|}
\hline \multirow[b]{2}{*}{ Year } & \multicolumn{3}{|c|}{ Web of Science } & \multicolumn{3}{|c|}{ Scopus } \\
\hline & $\begin{array}{c}\text { Number of } \\
\text { Publications }\end{array}$ & $\begin{array}{c}\text { Cumulative Number } \\
\text { of Publications }\end{array}$ & $\begin{array}{c}\text { Total } \\
\text { Citations } \\
\end{array}$ & $\begin{array}{c}\text { Number of } \\
\text { Publications }\end{array}$ & $\begin{array}{c}\text { Cumulative Number } \\
\text { of Publications }\end{array}$ & $\begin{array}{c}\text { Total } \\
\text { Citations } \\
\end{array}$ \\
\hline 2005 & 1 & 1 & 0 & 0 & 0 & 0 \\
\hline 2006 & 0 & 1 & 0 & 0 & 0 & 0 \\
\hline 2007 & 0 & 1 & 0 & 0 & 0 & 0 \\
\hline 2008 & 0 & 1 & 0 & 1 & 1 & 0 \\
\hline 2009 & 0 & 1 & 0 & 0 & 1 & 0 \\
\hline 2010 & 1 & 2 & 0 & 0 & 1 & 0 \\
\hline 2011 & 0 & 2 & 0 & 1 & 2 & 0 \\
\hline 2012 & 1 & 3 & 1 & 4 & 6 & 2 \\
\hline 2013 & 5 & 8 & 2 & 14 & 20 & 9 \\
\hline 2014 & 16 & 24 & 23 & 21 & 41 & 59 \\
\hline 2015 & 29 & 53 & 116 & 39 & 80 & 175 \\
\hline 2016 & 30 & 83 & 167 & 54 & 134 & 242 \\
\hline 2017 & 85 & 168 & 447 & 80 & 214 & 580 \\
\hline 2018 & 104 & 272 & 869 & 142 & 356 & 1235 \\
\hline 2019 & 83 & 355 & 1293 & 129 & 485 & 1907 \\
\hline 2020 & 0 & 355 & 3 & 4 & 489 & 73 \\
\hline
\end{tabular}

The analysis of the main research areas and categories of studies on the SSC, together with the most productive sources, authors, countries, and organizations in the field indicated that:

- Studies on the SSC covered diverse research areas. In the WoS database, the areas included, in particular, Science Technology other topics (102 records with $28.3 \%$ of all publications), Engineering (101, 28\%), and Computer Science $(87,24.1 \%)$. The most common were the following WoS-indexed categories: Green Sustainable Science Technology (101, 28\%), Urban Studies (66, 18.3\%), and Environmental Sciences $(61,16.9 \%)$. According to the Scopus database, SSC publications primarily concerned the following subject areas: Social Sciences (197 items with 40.3\% of all Scopus-indexed publications), Computer Science (192, 39.3\%), and Engineering (192, 39.3\%).

- The most productive sources of publications on the SSC in the WoS database were Sustainability (23 items), Sustainable Cities and Society (23), and the Journal of Cleaner Production (14). Most publications on the SSC indexed in the Scopus database appeared in Sustainable Cities and Society (27), Sustainability (26), the ACM International Conference Proceeding Series (14), and the Journal of Cleaner Production (14).

- The most prolific authors in the literature on the SSC, according to the WoS database, were Simon Elias Bibri (8 publications), Carl Adams (6), Ali El-Zaart (6), John Krogstie (6), and Tan Yigitcanlar (6). The most productive authors on the SSC recorded in the Scopus database were Simon Elias Bibri (26), John Krogstie (9), and Tan Yigitcanlar (7).

- The most active countries in the SSC literature field, according to the WoS database, were Italy (39 indexed records), Spain (37), the United Kingdom (36), and China (36). According to the Scopus database, the most productive countries in this field were Italy (52), the United Kingdom (51), and the United States (47).

- The most prolific organizations in the SSC academic field included in the WoS database were the Royal Institute of Technology (18 items), the Norwegian University of Science and Technology (11), and Queensland University of Technology (7). According to the Scopus database, the most productive 
entities were the same, but in a different order: the Norwegian University of Science and Technology (28), the Royal Institute of Technology (15), Queensland University of Technology (10).

The most productive authors, sources, countries, and organizations in the SSC literature field are presented in Tables A11 and A12 in Appendix A.

\subsection{Network Analysis}

\subsubsection{Word, Keyword, and Co-Keyword Analyses}

This subsection presents the results of the most frequently used words and keywords, the author keyword occurrence dynamic, and the co-occurrence network of author keywords in the SSC literature indexed in the WoS and Scopus databases.

The analysis of the most frequent words and keywords was based on the number of relevant wording occurrences in publications in the following types of categories: author keywords, words in titles, and words in abstracts. The analysis results showed that 1666 author keywords were used in the SSC literature. However, as shown in Table 7, there were only two author keywords that occurred more than a hundred times. Although the key topics of the papers under consideration were issues related to the SSC, due to the wide diversification of the concept forms used by authors, total occurrences of author keywords were much fewer than the number of publications. The authors used the terms, such as 'smart city', 'smart cities', 'sustainable city', 'sustainable cities'. The main term 'smart and sustainable cities' appeared in keywords as 'smart sustainable city/cities', 'sustainable smart city/cities', 'sustainable and smart city/cities'. It was decided to show them in the original version separately as used by respective authors. The analysis revealed that the most frequent keywords were as follows: 'smart city', 'smart cities', 'sustainability', 'sustainable city', 'sustainable development', and 'smart sustainable cities'.

Table 7. Most frequently used words and keywords in the SSC literature.

\begin{tabular}{cccccc}
\hline Author Keywords & Occurrences & Words in Titles & Occurrences & Words in Abstracts & Occurrences \\
\hline Smart city & 168 & Smart & 478 & Smart & 1833 \\
Smart cities & 113 & Cities & 309 & City & 1387 \\
Sustainability & 72 & Sustainable & 272 & Cities & 1379 \\
Sustainable city & 42 & City & 220 & Sustainable & 966 \\
Sustainable & 40 & Urban & 103 & Urban & 897 \\
development & 37 & Sustainability & 81 & Development & 607 \\
Smart sustainable cities & 37 & Development & 79 & Data & 442 \\
Sustainable cities & 29 & Data & 46 & Sustainability & 426 \\
Internet of things & 26 & Case & 38 & Paper & 404 \\
ICT & 25 & Planning & 35 & Energy & 331 \\
Urban sustainability & & & & & \\
\hline
\end{tabular}

In the next step, the dynamic of the time-dependent occurrence of author keywords was investigated. It could be seen in Figure 2 that the number of all main-term occurrences per year increased over time, but some of them grew more dynamically than others. The terms with the highest increase in occurrences over time were: 'smart city', 'smart cities', 'sustainability', 'sustainable cities', and 'sustainable development'.

To visualize the research hotspots in the SSC scientific field, the co-occurrence of author keywords was analyzed. The keyword co-occurrence threshold was set to three, and 122 keywords out of 1666 were classified as visualization items. The keyword co-occurrence network is presented in Figure 3. The size of the circles corresponded to the number of occurrences of the represented keywords. The larger the circle, the more the author keyword had been co-selected in the SSC literature. The topic similarity and its relative strength were demonstrated by the distance between the elements of individual pairs. Different colors of the circles were assigned to individual keyword clusters. The network in Figure 3 illustrates 16 distinct clusters, representing individual subfields of the research areas in the SSC literature. Table A13 in Appendix A presents the main parameters of the 
top 10 occurrences of author keywords in the SSC literature. The links between particular keywords indicated the number of papers in which the keywords co-occurred.

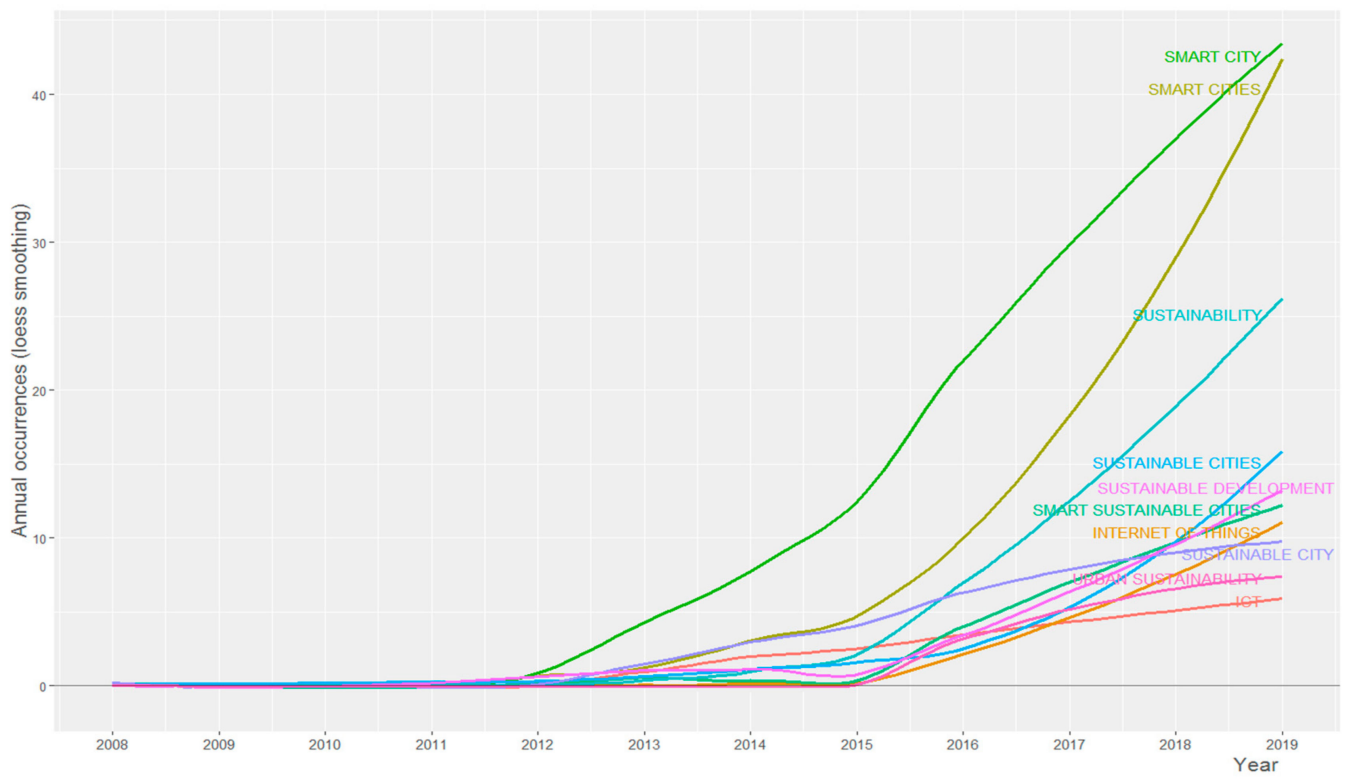

Figure 2. Dynamic of author keywords in the smart sustainable city (SSC) literature.

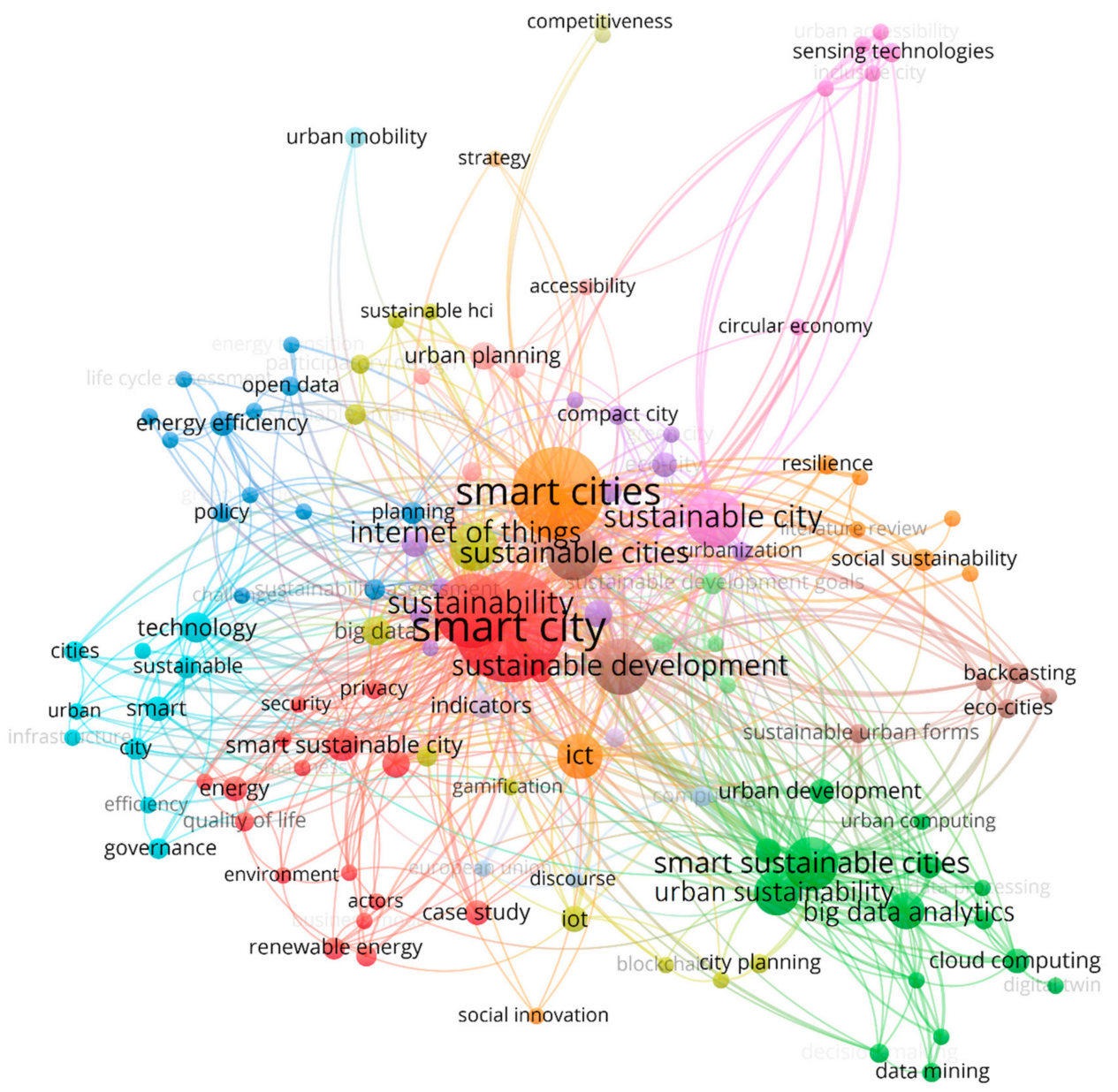

Figure 3. Co-occurrence network of author keywords (min. number of occurrences: three) in the SSC literature. 
Analyzing Figure 3 and Table A13 in Appendix A, it could be concluded that:

- The core topics in the SSC literature with the highest total link strength were: 'smart city/cities', 'sustainable city/cities', 'sustainable development', 'ICT', 'big data analytics', and 'urban sustainability'.

- Sixteen subfields (clusters of author keywords) were identified in the SSC scientific field, and the five main subfields were as follows:

- red cluster grouping together such keywords as 'smart city', 'sustainability', 'smart sustainable city', 'innovation', 'smart mobility', 'renewable energy', 'case study';

- green cluster grouping together such keywords as 'smart sustainable cities', 'urban sustainability', 'big data analytics', 'context-aware computing', 'cloud computing', 'environmental sustainability';

yellow cluster grouping together such keywords as 'internet of things', 'iot', 'big data', 'information and communication technology', 'sustainable smart cities', 'city planning';

$\bigcirc$ purple cluster grouping together such keywords as 'sustainable urban development', 'sustainable smart city', 'eco-city', 'climate changes', 'urbanization', 'green city';

○ light blue cluster grouping together such keywords as 'technology', 'smart', 'sustainable', 'city', 'cities', 'governance'.

The obtained results demonstrated a considerable diversity of the co-occurrence of author keywords in individual publications in the SSC literature. This proved the multi-faceted and multi-dimensional character of this particular scientific field.

\subsubsection{Mapping Scientific Collaboration}

Regional collaboration and research hotspots could be provided with the visualization of co-authorship occurrences of countries. The network illustrating such co-occurrences between countries in the SSC literature is presented in Figure 4. The size of the circles represented the number of occurrences of documents. The collaboration strength was demonstrated by the distance between circles in individual pairs. Different colors of circles were assigned to individual collaboration camps. In addition, Table A14 in Appendix A lists the main parameters of the top 10 occurrence countries. The total link strength of a country indicated the number of papers in which the authors of a given publication represent the two countries involved.

Analyzing the created network, it could be seen that:

- there were 66 countries represented by authors collaborating in the SSC literature;

- the United Kingdom and the United States were the countries with the greatest total link strength when it comes to an international collaboration of authors;

- Italy, Spain, India, and Norway had a high number of publications, but their international collaboration strength was relatively low.

The next step was the country-by-country citation analysis. Figure 5 shows the citation network of countries, illustrating mutual international citations in the SSC literature. The size of the relevant figures depended on the number of publications in a given country. The distance between two circles representing two different countries reflected the number of mutual citations of authors coming from them. The more often authors from one country cited authors from another, the shorter was the distance between two circles representing two different countries in the presented network. The links number (i.e., the number of other countries linked to the analyzed country by citations) and the total link strength (i.e., the number of all citations of authors coming from the country) for the top 10 countries are listed in Table A15 in Appendix A. 


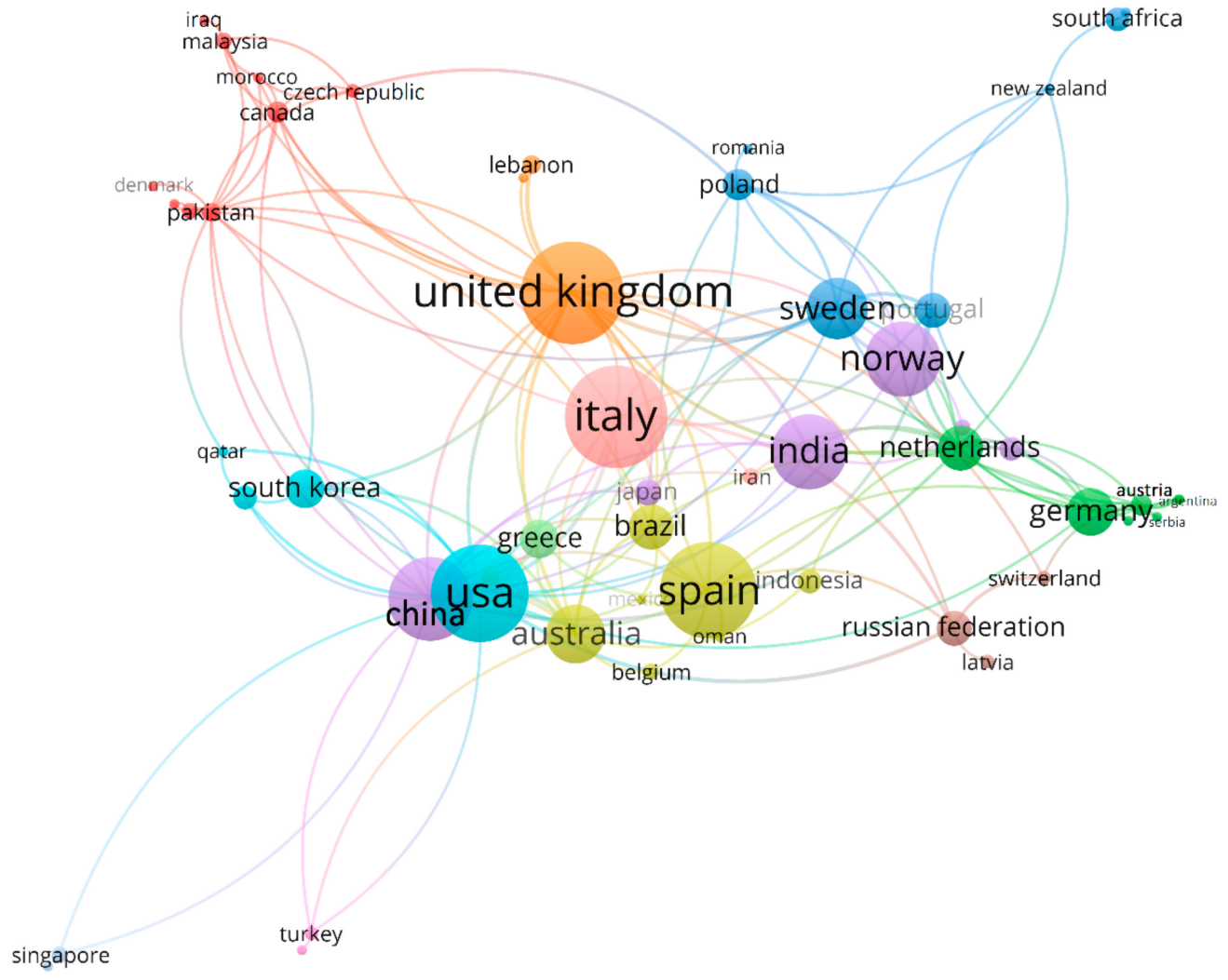

Figure 4. Co-authorship network of countries (min. number of publications: one) in the SSC literature.

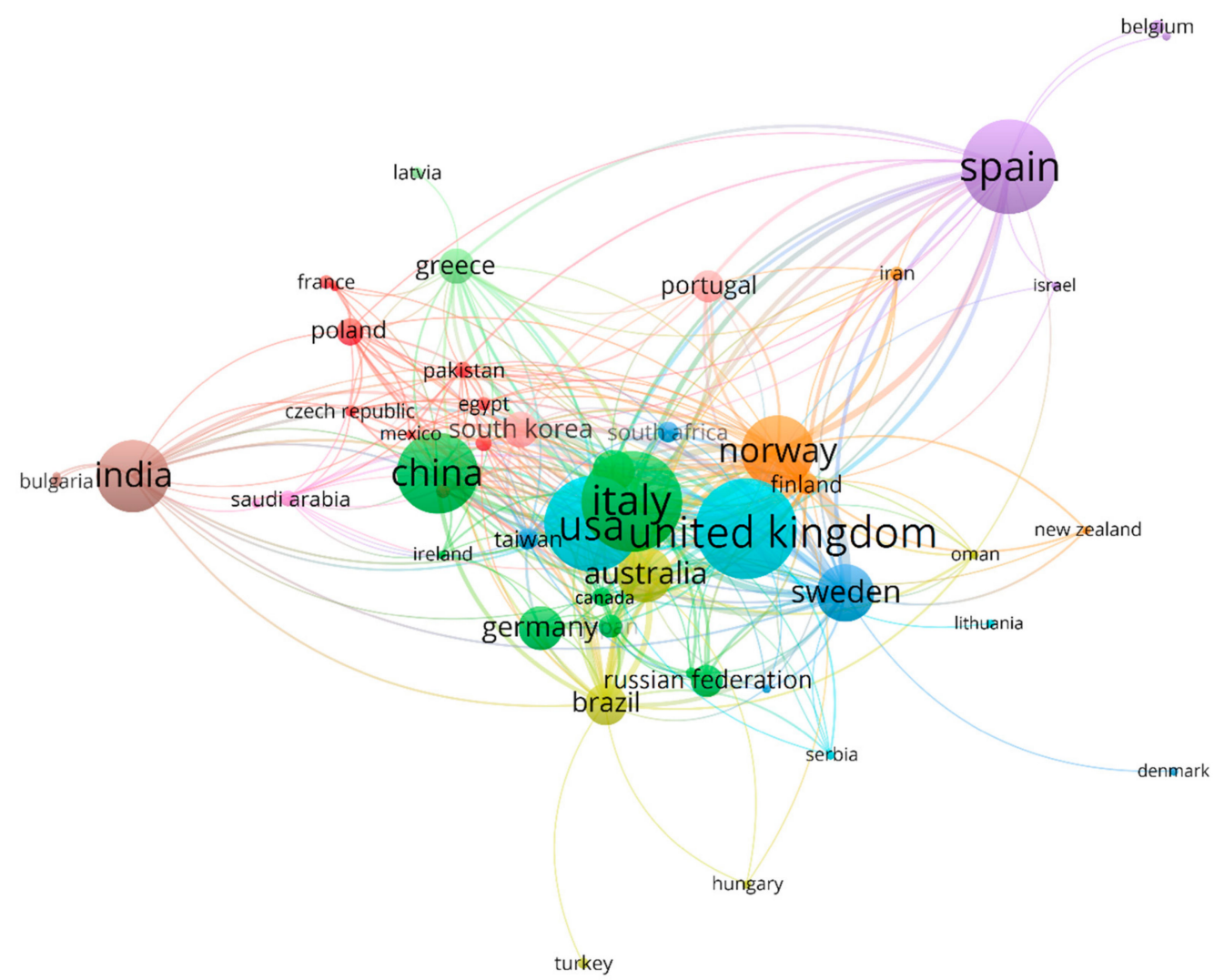

Figure 5. Citation network of countries (min. number of publications: one) in the SSC literature. 
Analyzing the created network, it could be seen that:

- there were 50 countries whose publications in the SSC literature had been cited by foreign authors;

- Italy, the United States, and the Netherlands were characterized by the closest academic relationship;

- there were several scientific communities that had published in the SSC literature, and the biggest two were the following groups of countries: (1) Italy, Australia, the United States, and the Netherlands and (2) Norway, Sweden, the United Kingdom, and Finland;

- despite the smaller number of publications, the international significance of countries, such as Sweden, Australia, Brazil, Finland, South Korea, Greece, Taiwan, and Canada, was relatively high (i.e., high total link strength relative to the number of publications).

Collaboration and significance of individual sources in the creation of the SSC knowledge were covered by the source-citation analysis. The source was understood as a journal, a book, or proceedings indexed in the WoS and Scopus databases. Figure 6 shows the network of mutual citations of different sources of the SSC literature. The size of the circles in the figure depended on the number of publications of a given source. The distance between two circles representing two different sources reflected the number of their mutual citations. The more often the publications of a given source cited the other source publications, the shorter was the distance between the two sources in the network presented in the figure. The links number (i.e., the number of other sources related to the analyzed source through citations) and the total link strength (i.e., the number of the source total citations) for the top 10 sources are listed in Table A16.

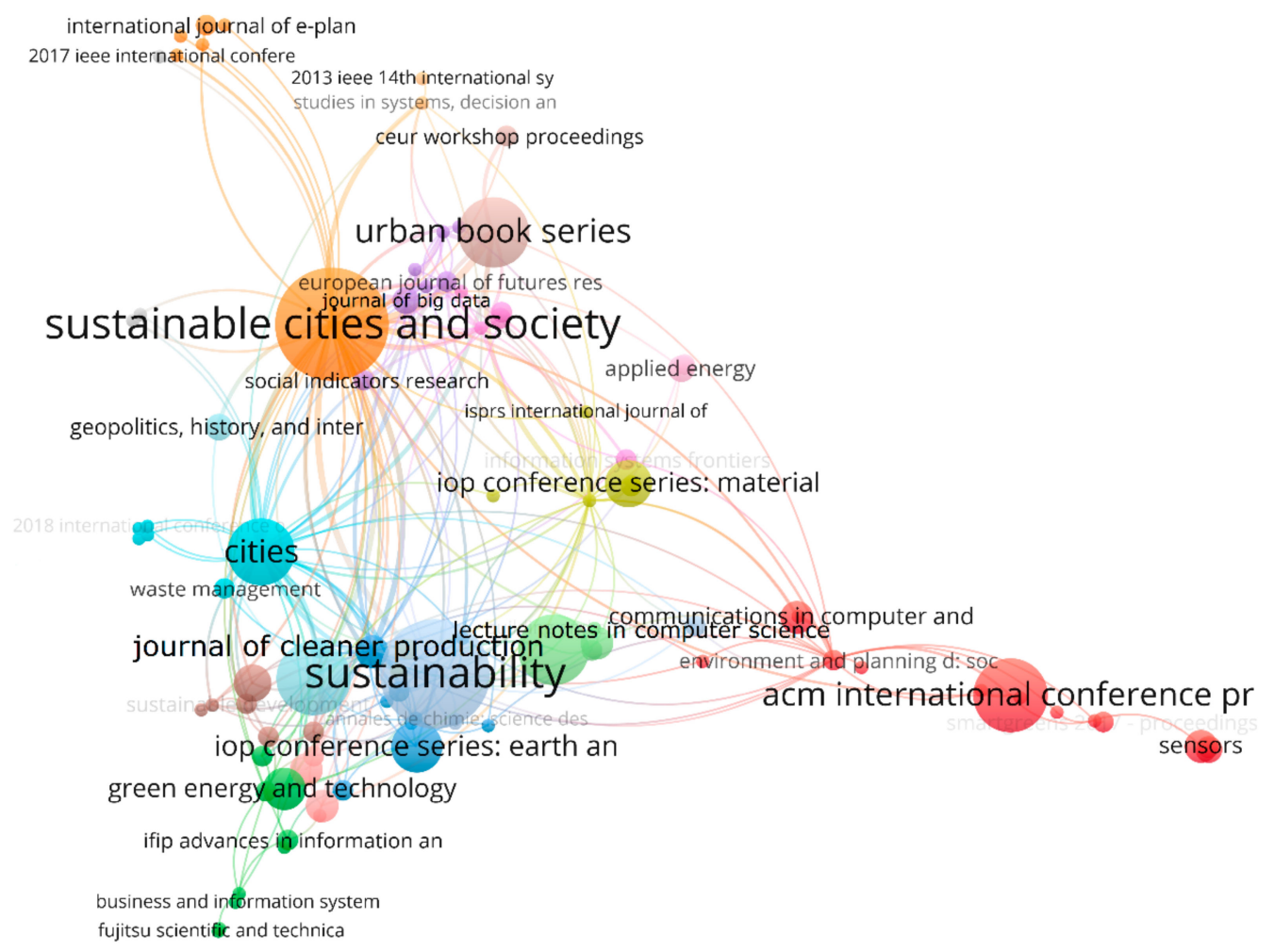

Figure 6. Citation network of sources (min. number of documents: one) in the SSC literature.

Analyzing the created network, it could be seen that:

- there were 99 sources whose publications in the SSC literature had been cited by another source and had created the network;

- there were two groups of significant sources with strong mutual relations: (1) Sustainability, the Journal of Cleaner Production, the IOP Conference Series and Lecture Notes in Computer Science and (2) Sustainable Cities and Society, the Urban Book Series, and the Journal of Big Data; 
- there were several top sources with a high value of the total link strength, including Sustainable Cities and Society (total link strength: 191), Cities (95), Technological Forecasting and Social Change (70), and Sustainability (66).

\subsubsection{Top Authors, Sources, and Keywords Relations}

The relations between the main authors' keywords, authors, and sources were visualized using the Three Fields Plot. In this case, the relevant elements were represented in the diagram by rectangles with a different color. The height of the rectangles depended on the value of the sum of the relations arising between the element that the rectangle represents (one of the elements in the authors' keyword, author, and source diagram) and the diagram of other elements. The more relations the element had, the higher was the rectangle representing it.

Figure 7 presents the diagram for research in the SSC literature, focusing on relations between the main authors' keywords, authors, and sources. The analysis demonstrated in which sources the authors of SSC publications had published most frequently and which research topics of the SSC concept they had explored. The research topics were understood here as the authors' keywords. The analysis of the top authors, sources, and keywords indicated that there were three authors (i.e., Simon Elias Bibri, John Krogstie, and Tan Yigitcanlar) and five sources (i.e., Sustainable Cities and Society, Cities, Sustainability, the Journal of Cleaner Production, and the Urban Book Series) having strong relations with the SSC literature main research topics ('smart sustainable cities', 'smart cities', and 'smart city', in particular).

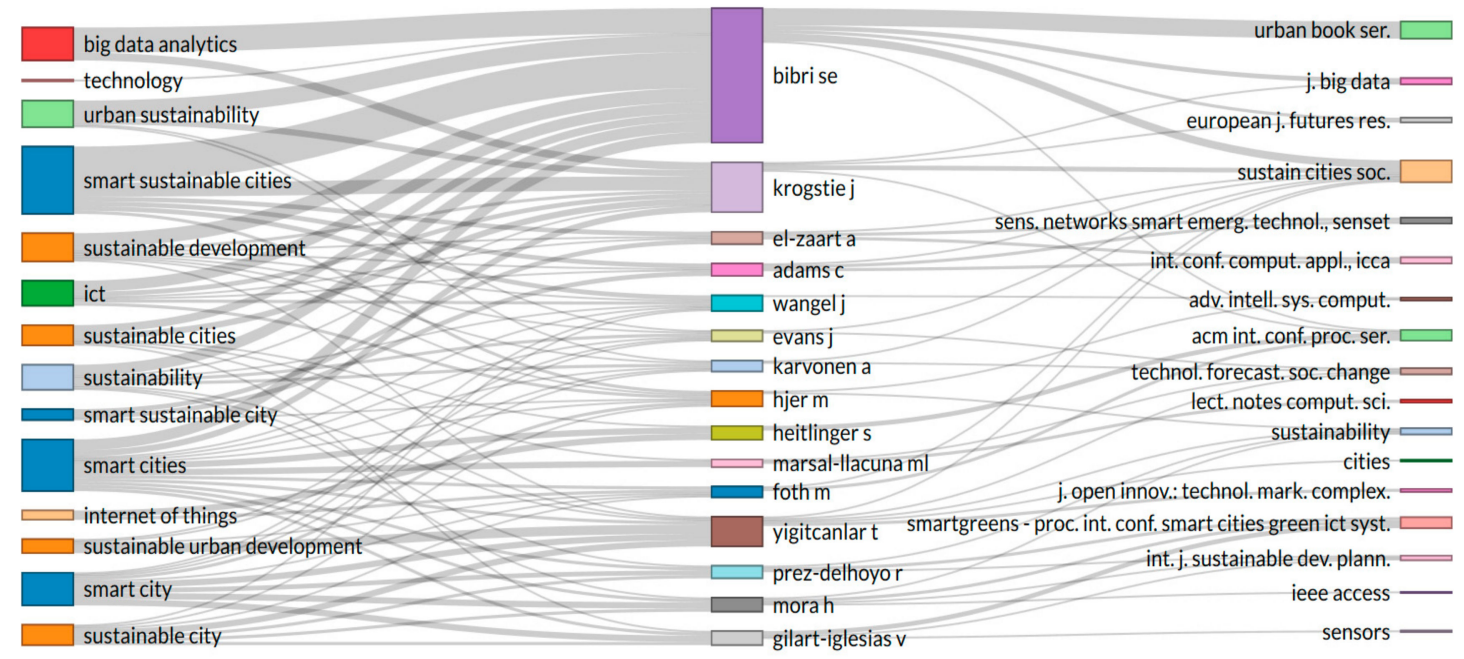

Figure 7. Relations between author keywords (left), authors (middle), and sources (right) for research in the SSC literature.

In addition, Figure 8 shows the relations between the main authors' keywords, sources, and cited sources. This diagram demonstrated the structure of top sources of publications (as the source and cited source) in developing the knowledge in the main topics in the SSC literature. The topics were represented by the authors' keywords, and the source or cited source significance was represented by the number of relevant relations. The analysis showed that the key sources of publications based on their contribution to the exploration of the SSC literature's main topics were Sustainable Cities and Society, the Journal of Cleaner Production, Sustainability, Cities, and the Urban Book Series. 


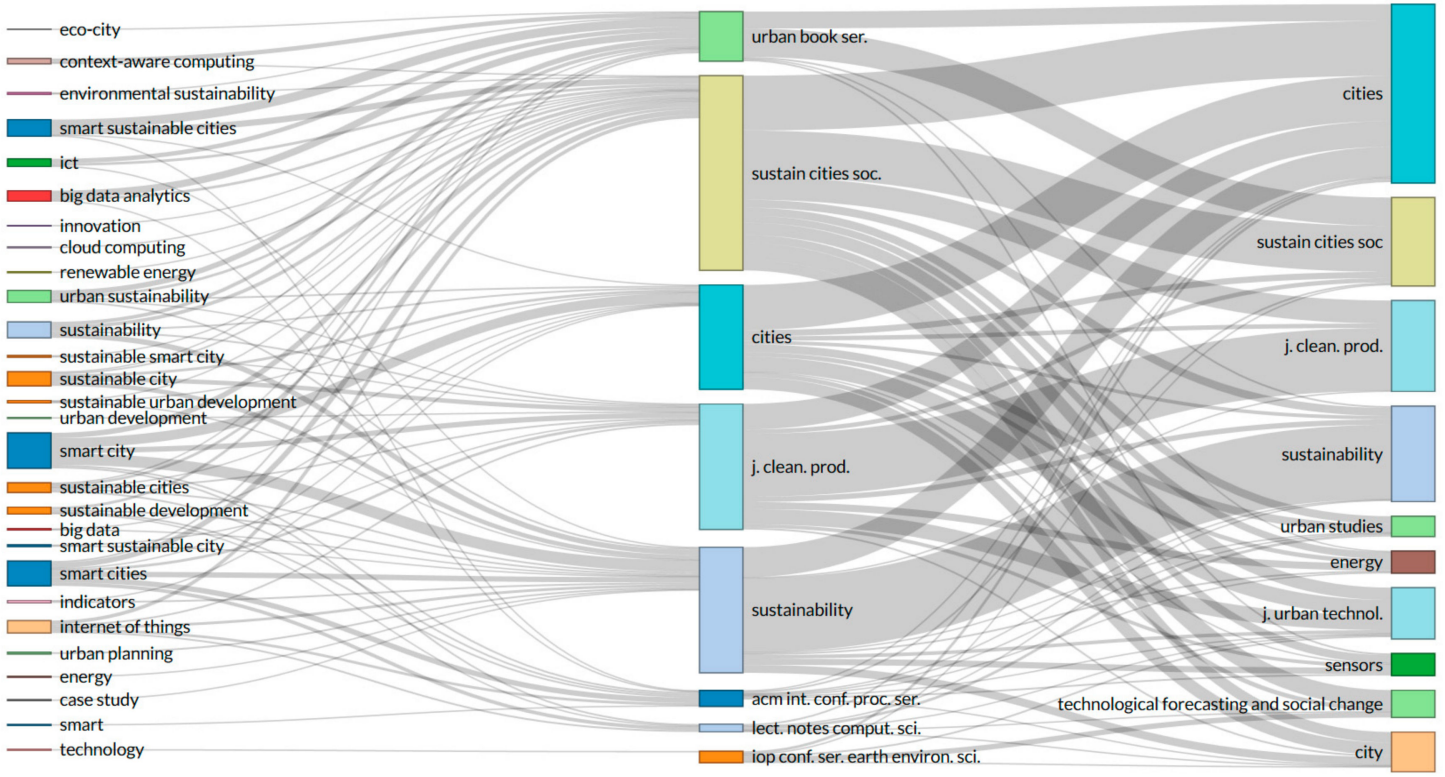

Figure 8. Relations between author keywords (left), sources (middle), and cited sources (right) for research in the SSC literature.

\section{Conclusions and Directions for Future Research}

Considering that, in the coming years, the number of city inhabitants worldwide would continue to grow, it is extremely important to find solutions that would allow cities to meet the challenges of urbanization. One of them is the SSC concept, but its implementation requires changes at all levels of the city [11]. Therefore, scholars and policymakers responsible for urban development should have extensive theoretical knowledge in this field. They should also familiarize themselves with the achievements and failures of cities that have already implemented the SSC concept to benefit from their positive experience and avoid repeating their mistakes.

For this reason, this article presented the scientific landscape of the SSC based on a bibliometric analysis of 1983-2020 publications recorded in the WoS and Scopus databases. Apart from SSC publications, the analysis also covered publications in the field of the SC and the SuC because the SC and SuC concepts influenced the development of the SSC notion significantly. Because the bibliometric analysis enabled a systematic and transparent review process based on the statistical measurement of science, scholars, or scientific activities, it was possible to identify how the SSC concept and the research trends have changed over the years and what research directions in the SSC field should be considered in the future.

The literature review indicated that the SSC notion is based on a blend of two complex concepts, the SC and the SuC. In general, it could be stated that the SC focuses on the interconnectedness and advancement of the physical, IT, social and business infrastructure to support the city's collective intelligence, while the SuC integrates environmental, economic, and social considerations to meet the goals of sustainable development. The SSC integrates the two concepts of urban development, but according to different authors, these are approached differently, depending on the starting point for creating the SSC. For some, the SSC is a sustainable city that should become smart because thanks to intelligent solutions, it would be able to meet the challenges of urbanization and achieve the goals of sustainable development $[38,58,59]$. Others suggest that the starting point for the SSC creation is smart city, which should not focus on technology and smart solutions only but should also take account of the impact of these solutions on the development of the social, economic, and environmental capital $[7,12]$. As a result, the scope of the research is very wide, and the directions of the SSC concept development are varied and cover diverse scientific areas.

The bibliometric analysis results proved that the number of publications on the SC, SuC, and SSC concepts increased year by year. However, there were substantially fewer publications on the SSC than on the other two concepts. Undoubtedly, this was due to the fact that the SSC concept is the newest, 
and the authors of the highest number of publications in the field started their publishing activity only in 2014. This might point to a great current interest in this research area on the one hand, and to its enormous potential on the other.

The descriptive bibliometric analysis indicated that studies on the SSC covered diverse research areas, such as Social Sciences, Computer Science, and Engineering, in particular. The most productive sources of publications on the SSC included Sustainable Cities and Society, Sustainability, the ACM International Conference Proceeding Series, and the Journal of Cleaner Production. Indisputably, the most prolific author in this area was Simon Elias Bibri. It must be noted that the publishing activity of the above-mentioned researcher had increased significantly in recent years. However, the SSC scientific landscape was mainly shaped by authors from the countries, such as Italy, the United Kingdom, the United States, Spain, and China. In addition, considering the affiliations of scientists focusing on the SSC concept, a few organizations should be distinguished. This especially concerned the Royal Institute of Technology, the Norwegian University of Science and Technology, and the Queensland University of Technology.

The network analysis resulted in more interesting findings. The co-occurrence network of authors' keywords revealed that research in the SSC area primarily concerned the following topics: 'smart city/cities', 'sustainability', 'sustainable city/cities', 'sustainable development', and 'smart sustainable cities'. However, the clusters obtained from the network analysis of authors' keywords demonstrated a considerable diversity of the co-occurrence of various topics (i.e., author keywords) in individual publications in the SSC literature. For example, the 'smart sustainable city' keyword co-occurred, in particular, with such other keywords as 'smart city', 'sustainability', 'innovation', 'smart mobility', and 'renewable energy'. The 'smart sustainable cities' keyword co-occurred with 'urban sustainability', 'big data analytics', 'context-aware computing', 'cloud computing', and 'environmental sustainability'. In contrast, 'sustainable smart city' co-occurred with 'sustainable urban development', 'eco-city', 'climate changes', 'urbanization', and 'green city'. This proved the multi-faceted and multi-dimensional character of this particular scientific field. Moreover, it seemed to be an interesting topic for further investigation based on a thorough review of the SSC literature.

The results of the countries' cooperation network analysis proved that there were two countries (i.e., the United Kingdom and the United States), which are definite leaders in the field of co-authorship. However, the citation network of countries showed that other countries (i.e., Norway, Italy, and Sweden) have had the closest relations in this kind of collaboration. The citation network of sources analysis revealed that there were two groups of significant sources cooperating in the SSC literature: (1) Sustainability, the Journal of Cleaner Production, the IOP Conference Series, and Lecture Notes in Computer Science and (2) Sustainable Cities and Society, the Urban Book Series, and the Journal of Big Data.

The bibliometric analysis identified the most frequent topics (i.e., author keywords) and also the most productive authors, sources, countries, and organizations in the SSC literature. Indicating the sources with the highest productivity and citations, these results could be used by future authors of SSC publications to adopt an appropriate publication strategy. Moreover, the analysis provided valuable information about the most active countries and academic organizations, as well as the most influential authors in the field of the SSC, which could become the basis for establishing future collaboration. The results of the analysis could also be useful for practitioners and decision-makers in cities because they could indicate publications, which are the most influential in terms of the SSC concept development, as evidenced by the number of citations that these publications receive.

In addition, the analysis results proved that, so far, most publications indexed in the WoS and Scopus databases have focused on showing the SSC concept theoretical foundations. There were also publications describing practical aspects of the SSC concept implementation, but they usually related to the implementation of smart solutions in cities (e.g., [58-60]). The publications presenting the experience of cities in the implementation of the SSC concept were few (e.g., [61-63]), and an increase in its number could only be observed in the last two years. It should be noted, however, that most of them were based on the experiences of cities in developed countries. The number of publications concerning the SSC concept 
implementation in peripheral countries is very limited (e.g., [36,64]). Therefore, it seems important in the future to give more attention to research showing good experiences in the implementation of smart solutions that make it possible for cities to develop in a manner that could also be called sustainable.

The analysis of the SSC literature indicated some important research gaps and issues with a potential future contribution. In general, there are growing expectations that smart cities will drive sustainable development. For example, Martin et al. [61] identified the key tensions between smart city visions and the goals of sustainable urban development. Höjer and Wangel specified the main challenges for the SSC concept of practical use [9]. In addition, based on an extensive interdisciplinary literature review, Bibri and Krogstie [10] delivered a comprehensive overview of the existing gaps in research on the SSC of the future. It should be noted that there are promising recent research areas concerning a holistic approach to the SSC concept [65-67].

Although every effort has been made to perform the bibliometric analysis in the best and most accurate manner, the research has some limitations. The analysis presented in the article was based on WoS- and Scopus-indexed publications only. For this reason, it could not be assumed as fully complete as there might be other important SSC publications not included in the two databases. However, the WoS and Scopus databases alone ensure the highest quality standards. In addition, it must be noted that the number of publications exploring the SSC concept is expected to increase dynamically in the future. Therefore, the obtained results should be treated with caution because they might become obsolete rather fast. Nevertheless, the aim of this study was comprehensive quantitative up-to-date evaluation of the SSC scientific landscape to identify the most prolific authors, sources, institutions, and countries, to indicate the most influential research channels and impact from authors, sources, countries, and research topics, as well as to provide valuable information for further investigation and determine publication strategies.

Author Contributions: Conceptualization, A.J. and A.R.; methodology, A.J., A.R. and M.S.; software, M.S.; data curation, M.S.; writing—original draft preparation, A.J., A.R. and M.S.; writing—review and editing, A.J. and A.R.; visualization, A.R. and M.S. All authors have read and agreed to the published version of the manuscript.

Funding: The research presented in the article was supported by statutory work 13/990/BK_19/0138 carried out at the Faculty of Organization and Management, Silesian University of Technology.

Conflicts of Interest: The authors declare no conflict of interest.

\section{Appendix A}

Table A1. Most cited publications in the SC literature indexed in the WoS database.

\begin{tabular}{|c|c|c|c|}
\hline Authors & Title & Source Title & Times Cited \\
\hline $\begin{array}{c}\text { Zanella, A., Bui, N., Castellani, } \\
\text { A., Vangelista, L., Zorzi, M. } \\
\text { (2014) }\end{array}$ & $\begin{array}{l}\text { Internet of things for } \\
\text { smart cities }\end{array}$ & $\begin{array}{l}\text { IEEE Internet of Things } \\
\text { Journal, 1(1), 22-32 }\end{array}$ & 1425 \\
\hline $\begin{array}{l}\text { Caragliu A., Del Bo Ch., } \\
\text { Nijkamp, P. (2011) }\end{array}$ & Smart cities in Europe & $\begin{array}{c}\text { Journal of Urban } \\
\text { Technology, 18(2), 65-82 }\end{array}$ & 722 \\
\hline $\begin{array}{c}\text { Botta, A., De Donato, W., } \\
\text { Persico, V., Pescapé, A. (2016) }\end{array}$ & $\begin{array}{l}\text { Integration of cloud } \\
\text { computing and internet of } \\
\text { things: A survey }\end{array}$ & $\begin{array}{l}\text { Future Generation } \\
\text { Computer Systems 56, } \\
684-700\end{array}$ & 509 \\
\hline $\begin{array}{l}\text { Neirotti, P., De Marco, A., } \\
\text { Cagliano, A.C., Mangano, G., } \\
\text { Scorrano, F. (2014) }\end{array}$ & $\begin{array}{c}\text { Current trends in smart city } \\
\text { initiatives: Some } \\
\text { stylised facts }\end{array}$ & Cities, 38, 25-36 & 485 \\
\hline $\begin{array}{l}\text { Batty, M., Axhausen, K.W., } \\
\text { Giannotti, F. et al. (2012) }\end{array}$ & Smart cities of the future & $\begin{array}{c}\text { European Physical } \\
\text { Journal: Special Topics, } \\
\text { 214(1), 481-518 }\end{array}$ & 450 \\
\hline $\begin{array}{l}\text { Jin, J., Gubbi, J., Marusic, } \\
\text { S. et al. (2014) }\end{array}$ & $\begin{array}{l}\text { An information framework } \\
\text { for creating a smart city } \\
\text { through internet of things }\end{array}$ & $\begin{array}{l}\text { IEEE Internet of Things } \\
\text { Journal, 1, 2, 112-121 }\end{array}$ & 416 \\
\hline
\end{tabular}


Table A1. Cont.

\begin{tabular}{cccc}
\hline Authors & Title & Source Title & Times Cited \\
\hline $\begin{array}{c}\text { Albino, V., Berardi, U., } \\
\text { Dangelico, R.M. (2015) }\end{array}$ & $\begin{array}{c}\text { Smart cities: Definitions, } \\
\text { dimensions, performance, } \\
\text { and initiatives }\end{array}$ & $\begin{array}{c}\text { Journal of Urban } \\
\text { Technology, 22, 1, 3-21 }\end{array}$ & 391 \\
\hline Shapiro, J.M. (2006) & $\begin{array}{c}\text { Smart cities: Quality of life, } \\
\text { productivity, and the growth } \\
\text { effects of human capital }\end{array}$ & $\begin{array}{c}\text { Review of Economics } \\
\text { and Statistics, 88, 2, } \\
\text { 324-335 }\end{array}$ & 376 \\
\hline $\begin{array}{c}\text { Schaffers, H., Komninos, N., } \\
\text { Pallot, M. et al. (2011) }\end{array}$ & $\begin{array}{c}\text { Smart cities and the future } \\
\text { internet: Towards } \\
\text { cooperation frameworks for } \\
\text { open innovation }\end{array}$ & $\begin{array}{c}\text { Lecture Notes in } \\
\text { Computer Science, 6656, } \\
\text { 431-446 }\end{array}$ & 351 \\
\hline Mancarella, P. (2014) & $\begin{array}{c}\text { MES (multi-energy systems): } \\
\text { An overview of concepts and } \\
\text { evaluation models }\end{array}$ & Energy, 65, 1-17 & 342 \\
\hline
\end{tabular}

Table A2. Most cited publications in the SC literature indexed in the Scopus database.

\begin{tabular}{|c|c|c|c|}
\hline Authors & Title & Source Title & Times Cited \\
\hline $\begin{array}{l}\text { Bonomi, F., Milito, R., Zhu, J., } \\
\text { Addepalli, S. (2012) }\end{array}$ & $\begin{array}{l}\text { Fog computing and its role in } \\
\text { the internet of things }\end{array}$ & $\begin{array}{l}\text { MCC'12-Proceedings of } \\
\text { the 1st ACM Mobile } \\
\text { Cloud Computing } \\
\text { Workshop, 13-15 }\end{array}$ & 2264 \\
\hline $\begin{array}{c}\text { Zanella, A., Bui, N., } \\
\text { Castellani, A., Vangelista, L., } \\
\text { Zorzi, M. (2014) }\end{array}$ & $\begin{array}{c}\text { Internet of things for smart } \\
\text { cities }\end{array}$ & $\begin{array}{l}\text { IEEE Internet of Things } \\
\text { Journal, 1(1), 22-32 }\end{array}$ & 1917 \\
\hline $\begin{array}{l}\text { Caragliu A., Del Bo Ch., } \\
\text { Nijkamp, P. (2011) }\end{array}$ & Smart cities in Europe & $\begin{array}{c}\text { Journal of Urban } \\
\text { Technology, 18(2), 65-82 }\end{array}$ & 913 \\
\hline Hollands, R.G. (2008) & $\begin{array}{l}\text { Will the real smart city please } \\
\text { stand up? Intelligent, } \\
\text { progressive or } \\
\text { entrepreneurial? }\end{array}$ & City, 12(3), 303-320 & 892 \\
\hline $\begin{array}{l}\text { Chourabi, H., Nam, T., } \\
\text { Walker, S., et al. (2012) }\end{array}$ & $\begin{array}{l}\text { Understanding smart cities: } \\
\text { An integrative framework }\end{array}$ & $\begin{array}{c}\text { Proceedings of the } \\
\text { Annual Hawaii } \\
\text { International Conference } \\
\text { on System Sciences, } \\
2289-2297\end{array}$ & 808 \\
\hline Kitchin, R. (2014) & $\begin{array}{l}\text { The real-time city? Big data } \\
\text { and smart urbanism }\end{array}$ & GeoJournal, 79(1), 1-14 & 699 \\
\hline $\begin{array}{c}\text { Botta, A., De Donato, W., } \\
\text { Persico, V., Pescapé, } \\
\text { A. (2016) }\end{array}$ & $\begin{array}{l}\text { Integration of Cloud } \\
\text { computing and Internet of } \\
\text { Things: A survey }\end{array}$ & $\begin{array}{c}\text { Future Generation } \\
\text { Computer Systems 56, } \\
684-700\end{array}$ & 689 \\
\hline $\begin{array}{l}\text { Neirotti, P., De Marco, A., } \\
\text { Cagliano, A.C., Mangano, G., } \\
\text { Scorrano, F. (2014) }\end{array}$ & $\begin{array}{l}\text { Current trends in smart city } \\
\text { initiatives: Some stylised facts }\end{array}$ & Cities, 38, 25-36 & 643 \\
\hline Nam, T., Pardo, T.A. (2011) & $\begin{array}{l}\text { Conceptualizing smart city } \\
\text { with dimensions of technology, } \\
\text { people, and institutions }\end{array}$ & $\begin{array}{l}\text { ACM International } \\
\text { Conference Proceeding } \\
\text { Series, 282-291 }\end{array}$ & 595 \\
\hline $\begin{array}{l}\text { Batty, M., Axhausen, K.W., } \\
\text { Giannotti, F. et al. (2012) }\end{array}$ & Smart cities of the future & $\begin{array}{l}\text { European Physical } \\
\text { Journal: Special Topics, } \\
\text { 214(1), 481-518 }\end{array}$ & 594 \\
\hline
\end{tabular}


Table A3. Most productive authors, sources, countries, and organizations in the SC literature indexed in the WoS database.

\begin{tabular}{|c|c|c|c|c|c|c|c|}
\hline Author & $\begin{array}{c}\text { Number of } \\
\text { Publications }\end{array}$ & Source & $\begin{array}{c}\text { Number of } \\
\text { Publications }\end{array}$ & Country & $\begin{array}{l}\text { Number of } \\
\text { Publications }\end{array}$ & Organization & $\begin{array}{c}\text { Number of } \\
\text { Publications }\end{array}$ \\
\hline Neera Kumar & 28 & IEEE Access & 228 & China & 1269 & $\begin{array}{l}\text { Chinese Academy } \\
\text { of Sciences }\end{array}$ & 103 \\
\hline Burak Kantarci & 25 & Sensors & 222 & United States & 1264 & $\begin{array}{c}\text { University of } \\
\text { Bologna }\end{array}$ & 96 \\
\hline Enrique Alba & 24 & $\begin{array}{l}\text { Lecture Notes in } \\
\text { Computer Science }\end{array}$ & 216 & Italy & 1175 & $\begin{array}{l}\text { Polytechnic } \\
\text { University of } \\
\text { Milan }\end{array}$ & 95 \\
\hline Luis Munoz & 23 & Sustainability & 115 & Spain & 822 & $\begin{array}{c}\text { Consiglio } \\
\text { Nazionale delle } \\
\text { Ricerche }\end{array}$ & 88 \\
\hline Paolo Nesi & 23 & $\begin{array}{l}\text { IEEE Internet of } \\
\text { Things Journal }\end{array}$ & 91 & India & 795 & $\begin{array}{l}\text { University of } \\
\text { London }\end{array}$ & 87 \\
\hline Schahram Dustdar & 22 & $\begin{array}{l}\text { Future Generation } \\
\text { Computer Systems } \\
\text { the International } \\
\text { Journal of eScience }\end{array}$ & 88 & United Kingdom & 647 & $\begin{array}{c}\text { Centre National de } \\
\text { la Recherche } \\
\text { Scientifique }\end{array}$ & 86 \\
\hline Kim-Kwang Raymond Choo & 21 & $\begin{array}{c}\text { IEEE } \\
\text { Communications } \\
\text { Magazine }\end{array}$ & 80 & Germany & 445 & $\begin{array}{c}\text { Indian Institute of } \\
\text { Technology }\end{array}$ & 83 \\
\hline Renata Paola Dameri & 21 & $\begin{array}{l}\text { Sustainable Cities } \\
\text { and Society }\end{array}$ & 76 & France & 366 & $\begin{array}{c}\text { Polytechnic } \\
\text { University of Turin }\end{array}$ & 82 \\
\hline Luca Foschini & 21 & $\begin{array}{c}\text { IEEE Second } \\
\text { International } \\
\text { Smart Cities } \\
\text { Conference ISC2 } \\
2016\end{array}$ & 70 & Australia & 364 & $\begin{array}{l}\text { Polytechnic } \\
\text { University of } \\
\text { Bucharest }\end{array}$ & 81 \\
\hline Jaime Lloret & 21 & $\begin{array}{c}\text { Advances in } \\
\text { Intelligent Systems } \\
\text { and Computing }\end{array}$ & 67 & Canada & 322 & $\begin{array}{c}\text { University of } \\
\text { Naples Federico II }\end{array}$ & 81 \\
\hline
\end{tabular}


Table A4. Most productive authors, sources, countries, and organizations in the SC literature indexed in the Scopus database.

\begin{tabular}{|c|c|c|c|c|c|c|c|}
\hline Author & $\begin{array}{l}\text { Number of } \\
\text { Publications }\end{array}$ & Source & $\begin{array}{l}\text { Number of } \\
\text { Publications }\end{array}$ & Country & $\begin{array}{l}\text { Number of } \\
\text { Publications }\end{array}$ & Organization & $\begin{array}{l}\text { Number of } \\
\text { Publications }\end{array}$ \\
\hline Paolo Nesi & 34 & Lecture Notes in Computer Science & 653 & China & 3613 & $\begin{array}{c}\text { Moscow State } \\
\text { University of Civil } \\
\text { Engineering }\end{array}$ & 194 \\
\hline Enrique Alba & 32 & ACM International Conference Proceeding Series & 562 & United States & 2254 & $\begin{array}{c}\text { Chinese Academy } \\
\text { of Sciences }\end{array}$ & 187 \\
\hline Schahram Dustdar & 29 & HPCC/SmartCity/DSS 2019 & 383 & India & 1740 & $\begin{array}{l}\text { Polytechnic } \\
\text { University of } \\
\text { Milan }\end{array}$ & 131 \\
\hline Luca Foschini & 27 & MATEC Web of Conferences & 346 & Italy & 1560 & $\begin{array}{l}\text { University of } \\
\text { Bologna }\end{array}$ & 121 \\
\hline Jaime Lloret & 26 & SmartWorld/UIC/ATC/ScalCom/CBDCom/IoP/SCI 2018 & 321 & United Kingdom & 1163 & $\begin{array}{l}\text { Czech Technical } \\
\text { University in } \\
\text { Prague }\end{array}$ & 114 \\
\hline Antonio Puliafito & 26 & Advances in Intelligent Systems and Computing & 305 & Spain & 1051 & $\begin{array}{l}\text { Tsinghua } \\
\text { University }\end{array}$ & 111 \\
\hline Arkady Zaslavsky & 26 & SmartWorld/SCALCOM/UIC/ATC/CBDCom/IOP/SCI 2017 & 283 & Germany & 740 & $\begin{array}{c}\text { Ministry of } \\
\text { Education China }\end{array}$ & 108 \\
\hline $\begin{array}{l}\text { Pierfrancesco } \\
\text { Bellini }\end{array}$ & 25 & HPCC/SmartCity/DSS 2018 & 249 & France & 605 & $\begin{array}{c}\text { Polytechnic } \\
\text { University of Turin }\end{array}$ & 108 \\
\hline Burak Kantarci & 25 & Communications in Computer and Information Science & 223 & Russia & 605 & Wuhan University & 107 \\
\hline Neera Kumar & 25 & Sensors & 219 & Australia & 531 & $\begin{array}{l}\text { Beihang } \\
\text { University }\end{array}$ & 104 \\
\hline
\end{tabular}


Table A5. Most cited publications in the SuC literature indexed in the WoS database.

\begin{tabular}{|c|c|c|c|}
\hline Authors & Title & Source Title & Times Cited \\
\hline Chiesura, A. (2004) & The role of urban parks for the sustainable city & $\begin{array}{l}\text { Landscape and Urban Planning, 68(1), } \\
\qquad 129-138\end{array}$ & 830 \\
\hline Kennedy, C., Cuddihy, J., Engel-Yan, J. (2007) & The changing metabolism of cities & Journal of Industrial Ecology, 11(2), 43-59 & 522 \\
\hline Bulkeley, H., Betsill, M.M. (2005) & $\begin{array}{l}\text { Rethinking sustainable cities: Multilevel governance and the 'urban' } \\
\text { politics of climate change }\end{array}$ & Environmental Politics, 14(1), 42-63 & 446 \\
\hline Neuman, M. (2005) & The compact city fallacy & $\begin{array}{l}\text { Journal of Planning Education and } \\
\text { Research, 25(1), 11-26 }\end{array}$ & 307 \\
\hline Portney, K.E. (2003) & $\begin{array}{l}\text { Taking sustainable cities seriously-Economic development, } \\
\text { the environment, and quality of life in American cities }\end{array}$ & $\begin{array}{l}\text { American and Comparative } \\
\text { Environmental Policy, 1-284 }\end{array}$ & 263 \\
\hline Haase, D., Frantzeskaki, N., Elmqvist, T. (2014) & $\begin{array}{l}\text { Ecosystem services in urban landscapes: Practical applications and } \\
\text { governance implications }\end{array}$ & AMBIO, 43, 4, 407-412 & 250 \\
\hline $\begin{array}{l}\text { Nevens, F., Frantzeskaki, N., Gorissen, L., } \\
\text { Loorbach, D. (2013) }\end{array}$ & $\begin{array}{l}\text { Urban transition labs: Co-creating transformative action for } \\
\text { sustainable cities }\end{array}$ & $\begin{array}{l}\text { Journal of Cleaner Production, 50, } \\
\qquad 111-122\end{array}$ & 217 \\
\hline Chang, C.-R., Li, M.-H., Chang, S.-D. (2007) & $\begin{array}{l}\text { A preliminary study on the local cool-island intensity of Taipei } \\
\text { city parks }\end{array}$ & $\begin{array}{l}\text { Landscape and Urban Planning, 80(4), } \\
\qquad 386-395\end{array}$ & 209 \\
\hline Bulkeley, H., Betsill, M.M. (2013) & Revisiting the urban politics of climate change & Environmental Politics, 22(1), 136-154 & 200 \\
\hline Kaushal, S.S., Belt, K.T. (2012) & $\begin{array}{c}\text { The urban watershed continuum: evolving spatial and } \\
\text { temporal dimensions }\end{array}$ & Urban Ecosystems, 15, 2, 409-435 & 178 \\
\hline
\end{tabular}


Table A6. Most cited publications in the SuC literature indexed in the Scopus database.

\begin{tabular}{|c|c|c|c|}
\hline Authors & Title & Source Title & Times Cited \\
\hline Chiesura, A. (2004) & $\begin{array}{l}\text { The role of urban parks for the } \\
\text { sustainable city }\end{array}$ & $\begin{array}{l}\text { Landscape and Urban Planning, 68(1), } \\
\qquad 129-138\end{array}$ & 945 \\
\hline Cohen, B. (2006) & $\begin{array}{l}\text { Urbanization in developing countries: } \\
\text { Current trends, future projections, and key } \\
\text { challenges for sustainability }\end{array}$ & Technology in Society, 28(1-2), 63-80 & 636 \\
\hline Kennedy, C., Cuddihy, J., Engel-Yan, J. (2007) & The changing metabolism of cities & Journal of Industrial Ecology, 11(2), 43-59 & 577 \\
\hline Bulkeley, H., Betsill, M.M. (2005) & $\begin{array}{l}\text { Rethinking sustainable cities: Multilevel } \\
\text { governance and the 'urban' politics of } \\
\text { climate change }\end{array}$ & Environmental Politics, 14(1), 42-63 & 519 \\
\hline Neuman, M. (2005) & The compact city fallacy & $\begin{array}{c}\text { Journal of Planning Education and } \\
\text { Research, 25(1), 11-26 }\end{array}$ & 377 \\
\hline Chang, C.-R., Li, M.-H., Chang, S.-D. (2007) & $\begin{array}{l}\text { A preliminary study on the local cool-island } \\
\text { intensity of Taipei city parks }\end{array}$ & $\begin{array}{l}\text { Landscape and Urban Planning, 80(4), } \\
\qquad 386-395\end{array}$ & 236 \\
\hline Bulkeley, H., Betsill, M.M. (2013) & $\begin{array}{l}\text { Revisiting the urban politics of } \\
\text { climate change }\end{array}$ & Environmental Politics, 22(1), 136-154 & 231 \\
\hline Nevens, F., Frantzeskaki, N., Gorissen, L., Loorbach, D. (2013) & $\begin{array}{l}\text { Urban transition labs: Co-creating } \\
\text { transformative action for sustainable cities }\end{array}$ & $\begin{array}{l}\text { Journal of Cleaner Production, 50, } \\
\qquad 111-122\end{array}$ & 217 \\
\hline Kenworthy, J.R. (2006) & $\begin{array}{l}\text { The eco-city: Ten key transport and planning } \\
\text { dimensions for sustainable city development }\end{array}$ & $\begin{array}{l}\text { Environment and Urbanization, 18(1), } \\
67-85\end{array}$ & 205 \\
\hline De Jong, M., Joss, S., Schraven, D., Zhan, C., Weijnen, M. (2015) & $\begin{array}{c}\text { Sustainable-smart-resilient-low } \\
\text { carbon-eco-knowledge cities; Making sense } \\
\text { of a multitude of concepts promoting } \\
\text { sustainable urbanization }\end{array}$ & Journal of Cleaner Production, 109, 25-38 & 204 \\
\hline
\end{tabular}


Table A7. Most productive authors, sources, countries, and organizations in the SuC literature indexed in the WoS database.

\begin{tabular}{|c|c|c|c|c|c|c|c|}
\hline Author & $\begin{array}{l}\text { Number of } \\
\text { Publications }\end{array}$ & Source & $\begin{array}{l}\text { Number of } \\
\text { Publications }\end{array}$ & Country & $\begin{array}{l}\text { Number of } \\
\text { Publications }\end{array}$ & Organization & $\begin{array}{l}\text { Number of } \\
\text { Publications }\end{array}$ \\
\hline Kent E. Portney & 24 & Sustainability & 107 & United States & 324 & University of London & 39 \\
\hline Sheldon Kamieniecki & 15 & $\begin{array}{c}\text { Sustainable Cities and } \\
\text { Society }\end{array}$ & 66 & United Kingdom & 216 & $\begin{array}{l}\text { Royal Institute of } \\
\text { Technology }\end{array}$ & 31 \\
\hline Michael E. Kraft & 15 & $\begin{array}{l}\text { WIT Transactions on } \\
\text { Ecology and the } \\
\text { Environment }\end{array}$ & 63 & China & 188 & University of California & 28 \\
\hline Tan Yigitcanlar & 10 & Cities & 45 & Australia & 136 & $\begin{array}{l}\text { Chinese Academy of } \\
\text { Sciences }\end{array}$ & 27 \\
\hline Peter Nijkamp & 9 & $\begin{array}{l}\text { Journal of Cleaner } \\
\text { Production }\end{array}$ & 44 & Italy & 124 & Arizona State University & 24 \\
\hline Simon Elias Bibri & 8 & $\begin{array}{c}\text { Advances in } \\
\text { Architecture Series }\end{array}$ & 30 & Spain & 100 & $\begin{array}{l}\text { University College } \\
\text { London }\end{array}$ & 23 \\
\hline Mattias Höjer & 8 & $\begin{array}{c}\text { Landscape and Urban } \\
\text { Planning }\end{array}$ & 23 & Germany & 93 & $\begin{array}{l}\text { Centre National de la } \\
\text { Recherche Scientifique }\end{array}$ & 21 \\
\hline Carl Adams & 6 & $\begin{array}{l}\text { Procedia Social and } \\
\text { Behavioral Sciences }\end{array}$ & 23 & Brazil & 91 & University of Wisconsin & 20 \\
\hline Ali El-Zaart & 6 & Procedia Engineering & 21 & Netherlands & 83 & $\begin{array}{l}\text { Norwegian University } \\
\text { of Science Technology }\end{array}$ & 17 \\
\hline John Krogstie & 6 & Habitat International & 19 & Canada & 72 & $\begin{array}{l}\text { University of Naples } \\
\text { Federico II }\end{array}$ & 17 \\
\hline
\end{tabular}


Table A8. Most productive authors, sources, countries, and organizations in the SuC literature indexed in the Scopus database.

\begin{tabular}{|c|c|c|c|c|c|c|c|}
\hline Author & $\begin{array}{l}\text { Number of } \\
\text { Publications }\end{array}$ & Source & $\begin{array}{l}\text { Number of } \\
\text { Publications }\end{array}$ & Country & $\begin{array}{l}\text { Number of } \\
\text { Publications }\end{array}$ & Organization & $\begin{array}{l}\text { Number of } \\
\text { Publications }\end{array}$ \\
\hline Simon Elias Bibri & 24 & $\begin{array}{l}\text { WIT Transactions on } \\
\text { Ecology and the } \\
\text { Environment }\end{array}$ & 111 & United States & 383 & University of Melbourne & 33 \\
\hline Peter Nijkamp & 11 & Sustainability & 105 & United Kingdom & 297 & $\begin{array}{c}\text { The Royal Institute of } \\
\text { Technology }\end{array}$ & 32 \\
\hline Kent E. Portney & 10 & $\begin{array}{l}\text { Sustainable Cities and } \\
\text { Society }\end{array}$ & 71 & Australia & 189 & $\begin{array}{l}\text { University College } \\
\text { London }\end{array}$ & 32 \\
\hline Tan Yigitcanlar & 10 & Cities & 42 & China & 175 & $\begin{array}{c}\text { Norwegian University } \\
\text { of Science and } \\
\text { Technology }\end{array}$ & 31 \\
\hline John Krogstie & 9 & $\begin{array}{l}\text { Journal of Cleaner } \\
\text { Production }\end{array}$ & 42 & Italy & 158 & $\begin{array}{c}\text { Chinese Academy of } \\
\text { Sciences }\end{array}$ & 31 \\
\hline Simon Marvin & 9 & $\begin{array}{c}\text { Advances in } \\
\text { Architecture Series }\end{array}$ & 30 & Spain & 122 & Arizona State University & 25 \\
\hline Stephanie Pincetl & 8 & $\begin{array}{l}\text { IOP Conference Series } \\
\text { Earth and } \\
\text { Environmental Science }\end{array}$ & 27 & Germany & 121 & $\begin{array}{c}\text { National University of } \\
\text { Singapore }\end{array}$ & 20 \\
\hline Virgilio Gilart-Iglesias & 7 & $\begin{array}{l}\text { World Sustainability } \\
\text { Series }\end{array}$ & 24 & France & 111 & $\begin{array}{l}\text { Delft University of } \\
\text { Technology }\end{array}$ & 19 \\
\hline Toshiharu Ikaga & 7 & $\begin{array}{l}\text { Landscape and Urban } \\
\text { Planning }\end{array}$ & 23 & Canada & 100 & $\begin{array}{c}\text { University of Naples } \\
\text { Federico II }\end{array}$ & 19 \\
\hline Steffen Lehmann & 7 & Local Environment & 23 & Netherlands & 99 & $\begin{array}{c}\text { University of } \\
\text { Manchester }\end{array}$ & 17 \\
\hline
\end{tabular}


Table A9. Most cited publications in the SSC literature indexed in the WoS database.

\begin{tabular}{|c|c|c|c|}
\hline Authors & Title & Source Title & Times Cited \\
\hline $\begin{array}{l}\text { Lee, J.H., Hancock, M.G., Hu, M.-C. } \\
\text { (2014) }\end{array}$ & $\begin{array}{c}\text { Towards an effective framework for building smart cities: Lessons } \\
\text { from Seoul and San Francisco }\end{array}$ & $\begin{array}{l}\text { Technological Forecasting and Social } \\
\text { Change, 89, 80-99 }\end{array}$ & 162 \\
\hline Cocchia, A. (2014) & Smart and digital city: A systematic literature review & $\begin{array}{l}\text { Smart City: How to Create Public and } \\
\text { Economic Value With High Technology } \\
\text { in Urban Space, } 13-43\end{array}$ & 160 \\
\hline $\begin{array}{l}\text { De Jong, M., Joss, S., Schraven, D., Zhan, } \\
\text { C., Weijnen, M. (2015) }\end{array}$ & $\begin{array}{c}\text { Sustainable-smart-resilient-low carbon-eco-knowledge cities: } \\
\text { Making sense of a multitude of concepts promoting sustainable } \\
\text { urbanization }\end{array}$ & Journal of Cleaner Production, 109, 25-38 & 158 \\
\hline Gabrys, J. (2014) & $\begin{array}{l}\text { Programming environments: Environmentality and citizen sensing } \\
\text { in the smart city }\end{array}$ & $\begin{array}{l}\text { Environment and Planning D: Society } \\
\text { and Space, } 32(1), 30-48\end{array}$ & 148 \\
\hline $\begin{array}{c}\text { Ahvenniemi, H., Huovila, A., } \\
\text { Pinto-Seppä, I., Airaksinen, M. (2017) }\end{array}$ & What are the differences between sustainable and smart cities? & Cities, 60, 234-245 & 138 \\
\hline Bibri, S.E., Krogstie, J. (2017) & $\begin{array}{l}\text { Smart sustainable cities of the future: An extensive interdisciplinary } \\
\text { literature review }\end{array}$ & $\begin{array}{l}\text { Sustainable Cities and Society, 31, } \\
\text { 183-212 }\end{array}$ & 109 \\
\hline McLaren, D., Agyeman, J. (2015) & Sharing cities: A case for truly smart and sustainable cities & $\begin{array}{l}\text { Book Series: Urban and Industrial } \\
\text { Environments, } 1-445\end{array}$ & 100 \\
\hline $\begin{array}{l}\text { Kramers, A., Höjer, M., Lövehagen, N., } \\
\text { Wangel, J. (2014) }\end{array}$ & $\begin{array}{c}\text { Smart sustainable cities-Exploring ICT solutions for reduced energy } \\
\text { use in cities }\end{array}$ & $\begin{array}{l}\text { Environmental Modelling and Software, } \\
\qquad 56,52-62\end{array}$ & 86 \\
\hline $\begin{array}{l}\text { Marsal-Llacuna, M.-L., Colomer-Llinàs, } \\
\text { J., Meléndez-Frigola, J. (2015) }\end{array}$ & $\begin{array}{l}\text { Lessons in urban monitoring taken from sustainable and livable } \\
\text { cities to better address the Smart Cities initiative }\end{array}$ & $\begin{array}{l}\text { Technological Forecasting and Social } \\
\text { Change, } 90,611-622\end{array}$ & 82 \\
\hline Yigitcanlar T., Lee S. (2014) & $\begin{array}{c}\text { Korean ubiquitous-eco-city: A smart-sustainable urban form or a } \\
\text { branding hoax? }\end{array}$ & $\begin{array}{l}\text { Technological Forecasting and Social } \\
\text { Change, } 89(1), 100-114\end{array}$ & 81 \\
\hline
\end{tabular}


Table A10. Most cited publications in the SSC literature indexed in the Scopus database.

\begin{tabular}{|c|c|c|c|}
\hline Authors & Title & Source Title & Times Cited \\
\hline $\begin{array}{l}\text { Lee, J.H., Hancock, M.G., } \\
\text { Hu, M.-C. (2014) }\end{array}$ & $\begin{array}{l}\text { Towards an effective framework for building smart cities: Lessons } \\
\text { from Seoul and San Francisco }\end{array}$ & $\begin{array}{l}\text { Technological Forecasting and Social } \\
\text { Change, 89, 80-99 }\end{array}$ & 217 \\
\hline $\begin{array}{l}\text { De Jong, M., Joss, S., Schraven, D., Zhan, } \\
\text { C., Weijnen, M. (2015) }\end{array}$ & $\begin{array}{l}\text { Sustainable-smart-resilient-low carbon-eco-knowledge cities: } \\
\text { Making sense of a multitude of concepts promoting sustainable } \\
\text { urbanization }\end{array}$ & Journal of Cleaner Production, 109, 25-38 & 205 \\
\hline Gabrys, J. (2014) & $\begin{array}{l}\text { Programming environments: Environmentality and citizen sensing } \\
\text { in the smart city }\end{array}$ & $\begin{array}{l}\text { Environment and Planning D: Society } \\
\text { and Space, 32(1), 30-48 }\end{array}$ & 180 \\
\hline $\begin{array}{l}\text { Ahvenniemi, H., Huovila, A., } \\
\text { Pinto-Seppä, I., Airaksinen, M. (2017) }\end{array}$ & What are the differences between sustainable and smart cities? & Cities, 60, 234-245 & 179 \\
\hline Zygiaris, S. (2013) & $\begin{array}{l}\text { Smart city reference model: Assisting planners to conceptualize the } \\
\text { building of smart city innovation ecosystems }\end{array}$ & $\begin{array}{l}\text { Journal of the Knowledge Economy, 4(2), } \\
\qquad 217-231\end{array}$ & 172 \\
\hline Bibri, S.E., Krogstie, J. (2017) & $\begin{array}{l}\text { Smart sustainable cities of the future: An extensive interdisciplinary } \\
\text { literature review }\end{array}$ & $\begin{array}{l}\text { Sustainable Cities and Society, 31, } \\
\qquad 183-212\end{array}$ & 160 \\
\hline McLaren, D., Agyeman, J. (2015) & Sharing cities: A case for truly smart and sustainable cities & $\begin{array}{l}\text { Book Series: Urban and Industrial } \\
\text { Environments, } 1-445\end{array}$ & 123 \\
\hline $\begin{array}{c}\text { Kramers, A., Höjer, M., Lövehagen, N., } \\
\text { Wangel, J. (2014) }\end{array}$ & $\begin{array}{l}\text { Smart sustainable cities - Exploring ICT solutions for reduced energy } \\
\text { use in cities }\end{array}$ & $\begin{array}{l}\text { Environmental Modelling and Software, } \\
\qquad 56,52-62\end{array}$ & 117 \\
\hline $\begin{array}{l}\text { Marsal-Llacuna, M.-L., Colomer-Llinàs, } \\
\text { J., Meléndez-Frigola, J. (2015) }\end{array}$ & $\begin{array}{l}\text { Lessons in urban monitoring taken from sustainable and livable } \\
\text { cities to better address the Smart Cities initiative }\end{array}$ & $\begin{array}{l}\text { Technological Forecasting and Social } \\
\text { Change, 90, 611-622 }\end{array}$ & 110 \\
\hline $\begin{array}{l}\text { Vilajosana, I., Llosa, J., Martinez, } \\
\text { B. et al. (2013) }\end{array}$ & $\begin{array}{l}\text { Bootstrapping smart cities through a self-sustainable model based on } \\
\text { big data flows }\end{array}$ & $\begin{array}{l}\text { IEEE Communications Magazine, } \\
51(6), 6525605,128-134\end{array}$ & 110 \\
\hline
\end{tabular}


Table A11. Most productive authors, sources, countries, and organizations in the SSC literature indexed in the WoS database.

\begin{tabular}{|c|c|c|c|c|c|c|c|}
\hline Author & $\begin{array}{l}\text { Number of } \\
\text { Publications }\end{array}$ & Source & $\begin{array}{l}\text { Number of } \\
\text { Publications }\end{array}$ & Country & $\begin{array}{l}\text { Number of } \\
\text { Publications }\end{array}$ & Organization & $\begin{array}{l}\text { Number of } \\
\text { Publications }\end{array}$ \\
\hline Simon Elias Bibri & 8 & Sustainability & 23 & Italy & 39 & $\begin{array}{c}\text { Royal Institute of } \\
\text { Technology }\end{array}$ & 18 \\
\hline Carl Adams & 6 & $\begin{array}{l}\text { Sustainable Cities and } \\
\text { Society }\end{array}$ & 23 & Spain & 37 & $\begin{array}{c}\text { Norwegian University } \\
\text { of Science and } \\
\text { Technology }\end{array}$ & 11 \\
\hline Ali El-Zaart & 6 & $\begin{array}{l}\text { Journal of Cleaner } \\
\text { Production }\end{array}$ & 14 & United Kingdom & 36 & $\begin{array}{l}\text { Queensland University } \\
\text { of Technology }\end{array}$ & 7 \\
\hline John Krogstie & 6 & Cities & 13 & China & 36 & Beirut Arab University & 6 \\
\hline Tan Yigitcanlar & 6 & $\begin{array}{c}\text { Innovation Technology } \\
\text { and Knowledge } \\
\text { Management }\end{array}$ & 7 & United States & 34 & $\begin{array}{l}\text { Indian Institute of } \\
\text { Technology }\end{array}$ & 6 \\
\hline Mattias Höjer & 5 & $\begin{array}{l}\text { Sustainable Smart Cities } \\
\text { Creating Spaces for } \\
\text { Technological Social and } \\
\text { Business Development }\end{array}$ & 6 & Sweden & 25 & University of Girona & 6 \\
\hline $\begin{array}{l}\text { Maria Lluïsa } \\
\text { Marsal-Llacuna }\end{array}$ & 5 & $\begin{array}{c}\text { Technological } \\
\text { Forecasting and Social } \\
\text { Change }\end{array}$ & 6 & India & 20 & $\begin{array}{l}\text { University of } \\
\text { Portsmouth }\end{array}$ & 6 \\
\hline James Evans & 4 & Energy Procedia & 5 & Brazil & 19 & $\begin{array}{l}\text { Consiglio Nazionale } \\
\text { delle Ricerche }\end{array}$ & 5 \\
\hline Maysoun Ibrahim & 4 & $\begin{array}{l}\text { IOP Conference Series } \\
\text { Materials Science and } \\
\text { Engineering }\end{array}$ & 5 & Australia & 17 & University of London & 5 \\
\hline Md Kamruzzaman & 4 & Urban Book Series & 5 & Norway & 16 & $\begin{array}{c}\text { University of Naples } \\
\text { Federico II }\end{array}$ & 5 \\
\hline
\end{tabular}


Table A12. Most productive authors, sources, countries, and organizations in the SSC literature indexed in the Scopus database.

\begin{tabular}{|c|c|c|c|c|c|c|c|}
\hline Author & $\begin{array}{l}\text { Number of } \\
\text { Publications }\end{array}$ & Source & $\begin{array}{l}\text { Number of } \\
\text { Publications }\end{array}$ & Country & $\begin{array}{l}\text { Number of } \\
\text { Publications }\end{array}$ & Organization & $\begin{array}{l}\text { Number of } \\
\text { Publications }\end{array}$ \\
\hline Simon Elias Bibri & 26 & $\begin{array}{l}\text { Sustainable Cities } \\
\text { and Society }\end{array}$ & 27 & Italy & 52 & $\begin{array}{c}\text { Norwegian University } \\
\text { of Science and } \\
\text { Technology }\end{array}$ & 28 \\
\hline John Krogstie & 9 & Sustainability & 26 & United Kingdom & 51 & $\begin{array}{l}\text { Royal Institute of } \\
\text { Technology }\end{array}$ & 15 \\
\hline Tan Yigitcanlar & 7 & $\begin{array}{c}\text { ACM International } \\
\text { Conference Proceeding } \\
\text { Series }\end{array}$ & 14 & United States & 47 & $\begin{array}{l}\text { Queensland University } \\
\text { of Technology }\end{array}$ & 10 \\
\hline Carl Adams & 6 & $\begin{array}{l}\text { Journal of Cleaner } \\
\text { Production }\end{array}$ & 14 & Spain & 46 & $\begin{array}{l}\text { Delft University of } \\
\text { Technology }\end{array}$ & 9 \\
\hline Ali El-Zaart & 6 & $\begin{array}{l}\text { Lecture Notes in } \\
\text { Computer Science }\end{array}$ & 13 & China & 39 & University of Alicante & 9 \\
\hline Virgilio Gilart-Iglesias & 6 & Urban Book Series & 13 & India & 34 & $\begin{array}{l}\text { University of } \\
\text { Manchester }\end{array}$ & 6 \\
\hline $\begin{array}{c}\text { Maria Lluïsa } \\
\text { Marsal-Llacuna }\end{array}$ & 6 & Cities & 12 & Norway & 34 & University of Girona & 6 \\
\hline Sara Heitlinger & 5 & ITU News & 9 & Sweden & 26 & $\begin{array}{c}\text { Polytechnic University } \\
\text { of Turin }\end{array}$ & 6 \\
\hline $\begin{array}{c}\text { María Dolores } \\
\text { Andújar-Montoya }\end{array}$ & 4 & $\begin{array}{l}\text { IOP Conference Series } \\
\text { Earth and } \\
\text { Environmental Science }\end{array}$ & 8 & Australia & 25 & $\begin{array}{l}\text { University College } \\
\text { London }\end{array}$ & 6 \\
\hline James Evans & 4 & $\begin{array}{l}\text { IOP Conference Series } \\
\text { Materials Science and } \\
\text { Engineering }\end{array}$ & 7 & Germany & 19 & $\begin{array}{l}\text { Polytechnic University } \\
\text { of Milan }\end{array}$ & 6 \\
\hline
\end{tabular}


Table A13. Main parameters of the top 10 authors' keywords (ranked by the total link strength) in the co-occurrence network of author keywords in the SSC literature.

\begin{tabular}{cccc}
\hline Keyword & Number of Links & Total Link Strength & Occurrences \\
\hline smart city & 84 & 266 & 168 \\
smart cities & 71 & 208 & 112 \\
sustainability & 65 & 173 & 72 \\
sustainable development & 46 & 121 & 40 \\
smart sustainable cities & 36 & 117 & 37 \\
sustainable city & 40 & 103 & 42 \\
sustainable cities & 39 & 93 & 37 \\
ICT & 33 & 88 & 26 \\
big data analytics & 22 & 74 & 17 \\
urban sustainability & 28 & 68 & 25 \\
\hline
\end{tabular}

Table A14. Main parameters of the top 10 countries (ranked by the total link strength) in the co-authorship network of countries in the SSC literature.

\begin{tabular}{cccc}
\hline Country & Number of Links & Total Link Strength & Documents \\
\hline United Kingdom & 22 & 44 & 51 \\
United States & 20 & 43 & 47 \\
China & 18 & 29 & 39 \\
Sweden & 12 & 26 & 26 \\
Italy & 14 & 24 & 52 \\
Australia & 11 & 24 & 25 \\
Netherlands & 16 & 22 & 18 \\
Spain & 12 & 17 & 46 \\
Pakistan & 14 & 14 & 6 \\
Brazil & 9 & 13 & 19 \\
\hline
\end{tabular}

Table A15. Main parameters of the top 10 countries (ranked by the total link strength) in the citation network of countries in the SSC literature.

\begin{tabular}{cccc}
\hline Country & Number of Links & Total Link Strength & Documents \\
\hline Norway & 26 & 212 & 34 \\
Italy & 34 & 192 & 52 \\
Sweden & 32 & 172 & 26 \\
United Kingdom & 33 & 143 & 51 \\
Australia & 29 & 140 & 25 \\
Brazil & 30 & 126 & 19 \\
Finland & 30 & 99 & 8 \\
Spain & 22 & 94 & 46 \\
United States & 21 & 93 & 47 \\
South Korea & 23 & 81 & 15 \\
\hline
\end{tabular}


Table A16. Main parameters of the top 10 sources in the citation network of sources (ranked by the total link strength) in the SSC literature.

\begin{tabular}{cccc}
\hline Country & Number of Links & Total Link Strength & Documents \\
\hline Sustainable Cities and Society & 49 & 191 & 27 \\
\hline Cities & 39 & 95 & 13 \\
\hline Technological Forecasting and Social Change & 29 & 70 & 6 \\
\hline Sustainability & 22 & 66 & 13 \\
\hline Urban Book Series & 8 & 60 & 1 \\
\hline Environmental Modelling and Software & 32 & 49 & 3 \\
\hline Journal of Cleaner Production & 14 & 34 & 1 \\
\hline Journal of Big Data & 10 & 26 & 2 \\
\hline $\begin{array}{c}\text { International Journal of Public Sector } \\
\text { Management }\end{array}$ & 13 & 23 & 26 \\
\hline $\begin{array}{c}\text { Journal of Open Innovation: Technology, } \\
\text { Market, and Complexity }\end{array}$ & 12 & & 2 \\
\hline
\end{tabular}

\section{References}

1. United Nations. World Urbanization Prospects: The 2018 Revision; (ST/ESA/SER.A/420); Department of Economic and Social Affairs, Population Division, United Nations: New York, UY, USA, 2019; pp. 9-32. [CrossRef]

2. Girardet, H. Creating Sustainable Cities, 1st ed.; Series: Schumacher Briefings; Green Book: Totnes, UK, 1999.

3. United Nations. New Urban Agenda HABITAT III; The United Nations Conference on Housing and Sustainable Urban Development (Habitat III): Quito, Ecuador, 2017; p. 3.

4. United Nations. Transforming Our World: The 2030 Agenda for Sustainable Development; Resolution Adopted by the General Assembly on 25 September 2015 (A/RES/70/1); United Nations: New York, UY, USA, 2015; pp. 15-31. [CrossRef]

5. Caragliu, A.; del Bo, C.; Nijkamp, P. Smart cities in Europe. J. Urban Technol. 2011, 18, 65-82. [CrossRef]

6. Silva, B.N.; Khan, M.; Han, K. Towards sustainable smart cities: A review of trends, architectures, components and open challenges in smart cities. Sustain. Cities Soc. 2018, 38, 697-713. [CrossRef]

7. Ahvenniemi, H.; Huovila, A.; Pinto-Seppä, I.; Airaksinen, M. What are the differences between sustainable and smart cities? Cities 2017, 60, 234-245. [CrossRef]

8. Yigitcanlar, T.; Lee, S. Korean ubiquitous-eco-city: A smart-sustainable urban form or a branding hoax? Technol. Forecast. Soc. 2014, 89, 100-114. [CrossRef]

9. Höjer, M.; Wangel, J. Smart Sustainable Cities: Definition and Challenges. In ICT Innovations for Sustainability. Advances in Intelligent Systems and Computing; Hilty, L.M., Aebischer, B., Eds.; Springer International Publishing: Cham, Switzerland, 2015; Volume 310, pp. 333-349. [CrossRef]

10. Bibri, S.E.; Krogstie, J. Smart sustainable cities of the future: An extensive interdisciplinary literature review. Sustain. Cities Soc. 2017, 31, 183-212. [CrossRef]

11. Ibrahim, M.; El-Zaart, A.; Adams, C. Smart sustainable cities roadmap: Readiness for transformation towards urban sustainability. Sustain. Cities Soc. 2018, 37, 530-540. [CrossRef]

12. Bouzguenda, I.; Alalouch, C.; Fava, N. Towards smart sustainable cities: A review of the role digital citizen participation could play in advancing social sustainability. Sustain. Cities Soc. 2019, 50, 101627. [CrossRef]

13. Yigitcanlar, T.; Kamruzzaman, M.; Foth, M.; Sabatini-Marques, J.; da Costa, E.; Ioppolo, G. Can cities become smart without being sustainable? A systematic review of the literature. Sustain. Cities Soc. 2019, 45, 348-365. [CrossRef]

14. Cocchia, A. Smart and Digital City: A Systematic Literature Review. In Smart City: How to Create Public and Economic Value with High Technology in Urban Space; Dameri, R.P., Rosenthal-Sabroux, C., Eds.; Springer International Publishing: Cham, Switzerland, 2014; pp. 13-43. [CrossRef] 
15. Guo, Y.M.; Huang, Z.L.; Guo, J.; Li, H.; Guo, X.R.; Nkeli, M.J. Bibliometric analysis on smart cities research. Sustainability 2019, 11, 3606. [CrossRef]

16. Gupta, P.; Chauhan, S.; Jaiswal, M.P. Classification of smart city research-A descriptive literature. Review and future research agenda. Inform. Syst. Front. 2019, 21, 661-685. [CrossRef]

17. Fu, Y.; Zhang, X. Trajectory of urban sustainability concepts: A 35-year bibliometric analysis. Cities 2017, 60, 113-123. [CrossRef]

18. Wang, M.-H.; Ho, Y.-S.; Fu, H.-Z. Global performance and development on sustainable city based on natural science and social science research: A bibliometric analysis. Sci. Total Environ. 2019, 666, 1245-1254. [CrossRef] [PubMed]

19. Trindade, E.P.; Hinnig, M.P.F.; Moreira da Costa, E.; Marques, J.S.; Bastos, R.C.; Yigitcanlar, T. Sustainable development of smart cities: A systematic review of the literature. J. Open Innov. Technol. Mark. Complex. 2017, 3, 1-14. [CrossRef]

20. Durieux, V.; Gevenois, P.A. Bibliometric indicators: Quality measurements of scientific publication. Radiology 2010, 255, 342-351. [CrossRef] [PubMed]

21. Harrison, C.; Eckman, B.; Hamilton, R.; Hartswick, P.; Kalagnanam, J.; Paraszczak, J.; Williams, P. Foundations for smarter cities. IBM J. Res. Dev. 2010, 54, 1-16. [CrossRef]

22. Hall, R.E.; Bowerman, B.; Braverman, J.; Taylor, J.; Todosow, H.; Von Wimmersperg, U. The vision of a smart city. In Proceedings of the 2nd International Life Extension Technology Workshop, Paris, France, 28 September 2000.

23. Giffinger, R.; Fertner, C.; Kramar, H.; Kalasek, R.; Pichler-Milanovic, N.; Meijers, E. Smart Cities: Ranking of European Medium-Sized Cities; Centre of Regional Science, Vienna University of Technology: Vienna, Austria, 2007.

24. Kourtit, K.; Nijkamp, P. Smart cities in the innovation age. Innov. Abingdon 2012, 25, 93-95. [CrossRef]

25. Yigitcanlar, T.; Kamruzzaman, M.; Buys, L.; Ioppolo, G.; Sabatini-Marques, J.; Moreira da Costa, E.; Yun, J.J. Understanding 'smart cities': Intertwining development drivers with desired outcomes in a multidimensional framework. Cities 2018, 81, 145-160. [CrossRef]

26. Angelidou, M. Smart city policies: A spatial approach. Cities 2014, 41 (Suppl. 1), S3-S11. [CrossRef]

27. Gutiérrez, V.; Theodoridis, E.; Mylonas, G.; Shi, F.; Adeel, U.; Diez, L.; Amaxilatis, D.; Choque, J.; Camprodom, G.; McCann, J.; et al. Co-creating the cities of the future. Sensors 2016, 16, 1971. [CrossRef]

28. Janik, A.; Ryszko, A. Scientific Landscape of Smart City Concept: A Bibliometric Analysis. In Proceedings of the 32nd International Business Information Management Association Conference (IBIMA), Seville, Spain, 15-16 November 2018; pp. 6254-6266.

29. Albino, V.; Berardi, U.; Dangelico, R.M. Smart cities: Definitions, dimensions, performance, and initiatives. J. Urban Technol. 2015, 22, 3-21. [CrossRef]

30. Meijer, A.; Bolivar, M.P.R. Governing the smart city: A review of the literature on smart urban governance. Int. Rev. Adm. Sci. 2016, 82, 392-408. [CrossRef]

31. Ewers, H.; Nijkamp, P. Urban Sustainability; Nijkamp, P., Ed.; Gower House: Avebury, UK, 1990.

32. United Nations. World Economic and Social Survey 2013. Sustainable Development Challenges; E/2013/50/Rev.1; Department of Economic and Social Affairs: New York, NY, USA, 2013.

33. Hiremath, R.B.; Balachandra, P.; Kumar, B.; Bansode, S.S.; Murali, J. Indicator-based urban sustainability-A review. Energy Sustain. Dev. 2013, 17, 555-563. [CrossRef]

34. Ibrahim, M.; Adams, C.; El-Zaart, A. Paving the way to smart sustainable cities: Transformation models and challenges. J. Inf. Syst. Technol. Manag. 2015, 12, 559-576. [CrossRef]

35. Bibri, S.E.; Krogstie, J. On the social shaping dimensions of smart sustainable cities: A study in science, technology, and society. Sustain. Cities Soc. 2017, 29, 219-246. [CrossRef]

36. Dhingra, M.; Chattopadhyay, S. Advancing smartness of traditional settlements-case analysis of Indian and Arab old cities. Int. J. Sustain. Built Environ. 2016, 5, 549-563. [CrossRef]

37. Bibri, S.E. A foundational framework for smart sustainable city development: Theoretical, disciplinary, and discursive dimensions and their synergies. Sustain. Cities Soc. 2018, 38, 758-794. [CrossRef]

38. Kramers, A.; Höjer, M.; Lövehagen, N.; Wangel, J. Smart sustainable cities: Exploring ICT solutions for reduced energy use in cities. Environ. Model. Softw. 2014, 56, 52-62. [CrossRef]

39. Waltman, L.; Eck, N.J.; Noyons, C.M. A unified approach to mapping and clustering of bibliometric networks. J. Informetr. 2010, 4, 629-635. [CrossRef] 
40. Waltman, L.; Eck, N.J. A smart local moving algorithm for large-scale modularity-based community detection. Eur. Phys. J. B 2013, 86. [CrossRef]

41. Eck, N.J.; Waltman, L. Visualizing bibliometric networks. In Measuring Scholarly Impact; Ding, Y., Rousseau, R., Wolfram, D., Eds.; Springer: Cham, Switzerland, 2014; pp. 285-320. [CrossRef]

42. Zhang, J.; Yu, Q.; Zheng, F.S.; Long, C.; Lu, Z.X.; Duan, Z.G. Comparing keyword plus of WoS and author keywords: A case study of patient adherence research. J. Assoc. Inf. Sci. Technol. 2016, 67, 967-972. [CrossRef]

43. Drohojowska, H. San Francisco style, Art-Deco elements inform a smart city residence + interior-design by arnold, Val. Archit. Digest 1991, 48, 114-121.

44. Shetty, V. A tale of smart cities. Commun. Int. 1997, 24, 16.

45. Zanella, A.; Bui, N.; Castellani, A.; Vangelista, L.; Zorzi, M. Internet of things for smart cities. IEEE Internet Things 2014, 1, 22-32. [CrossRef]

46. Botta, A.; De Donato, W.; Persico, V.; Pescapé, A. Integration of cloud computing and internet of things: A survey. Future Gener. Comp. Syst. 2016, 56, 684-700. [CrossRef]

47. Bonomi, F.; Milito, R.; Zhu, J.; Addepalli, S. Fog Computing and Its Role in the Internet of Things MCC'12. In Proceedings of the 1st ACM Mobile Cloud Computing Workshop, San Francisco, CA, USA, 22-26 June 2012; pp. 13-16. [CrossRef]

48. Cadman, D. Resourceful cities: Towards an ecology of finance. Town Country Plan. 1983, 52, 218-220.

49. Kennedy, D. Permaculture and the sustainable city. Ekistics 1991, 58, 210-215.

50. Chiesura, A. The role of urban parks for the sustainable city. Landsc. Urban Plan. 2004, 68, 129-138. [CrossRef]

51. Kennedy, C.; Cuddihy, J.; Engel-Yan, J. The changing metabolism of cities. J. Ind. Ecol. 2007, 11, 43-59. [CrossRef]

52. Cohen, B. Urbanization in developing countries: Current trends, future projections, and key challenges for sustainability. Technol. Soc. 2006, 28, 63-80. [CrossRef]

53. Bulkeley, H.; Betsill, M.M. Rethinking sustainable cities: Multilevel governance and the 'urban' politics of climate change. Environ. Polit. 2005, 14, 42-63. [CrossRef]

54. Lau, S.S.Y.; Wang, J.; Giridharan, R. Smart and sustainable city-A case study from Hong Kong. Smart Sustain. Built Environ. 2005, 33-42. [CrossRef]

55. Lee, J.H.; Hancock, M.G.; Hu, M.-C. Towards an effective framework for building smart cities: Lessons from Seoul and San Francisco. Technol. Forecast. Soc. 2014, 89, 80-99. [CrossRef]

56. De Jong, M.; Joss, S.; Schraven, D.; Zhan, C.; Weijnen, M. Sustainable-smart-resilient-low carbon-eco-knowledge cities: Making sense of a multitude of concepts promoting sustainable urbanization. J. Clean. Prod. 2015, 109, 25-38. [CrossRef]

57. Gabrys, J. Programming environments: Environmentality and citizen sensing in the smart city. Environ. Plan. D Soc. Space 2014, 32, 30-48. [CrossRef]

58. Bibri, S.E. The IoT for smart sustainable cities of the future: An analytical framework for sensor-based big data applications for environmental sustainability. Sustain. Cities Soc. 2018, 38, 230-253. [CrossRef]

59. Jamei, E.; Mortimer, M.; Seyedmahmoudian, M.; Horan, B.; Stojcevski, A. Investigating the role of virtual reality in planning for sustainable smart cities. Sustainability 2017, 9, 2006. [CrossRef]

60. Lim, H.S.M.; Taeihagh, A. Autonomous vehicles for smart and sustainable cities: An in-depth exploration of privacy and cybersecurity implications. Energies 2018, 11, 1062. [CrossRef]

61. Martin, C.J.; Evans, J.; Karvonen, A. Smart and sustainable? Five tensions in the visions and practices of the smart-sustainable city in Europe and North America. Technol. Forecast. Soc. 2018, 133, 269-278. [CrossRef]

62. Mahesa, R.; Yudoko, G.; Anggoro, Y. Dataset on the sustainable smart city development in Indonesia. Data Brief 2019, 25, 104098. [CrossRef]

63. Daptarda, V.; Gore, M. Smart cities for sustainable development in India: Opportunities and challenges. Eur. J. Sustain. Dev. 2019, 8, 133-144. [CrossRef]

64. El-Kholei, A.O.; Yassine, G. The mirage of smart sustainable cities in the Arab region. Open House Int. 2019, $44,8-16$.

65. Jonek-Kowalska, I.; Kaźmierczak, J.; Kramarz, M.; Hilarowicz, A.; Wolny, M. Introduction to the Research Project "Smart City: A Holistic Approach". In Proceedings of the 5th International Multidisciplinary Scientific Conference on Social Sciences and Arts SGEM 2018, SGEM2018 Conference Proceedings, Albena, Bulgaria, 24 August-2 September 2018; Volume 5, pp. 101-112. [CrossRef] 
66. Karwot, J.; Kaźmierczak, J.; Wyczółkowski, R.; Paszkowski, W.; Przystałka, P. "Smart Water in Smart City": A case study. In Proceedings of the 16th International Multidisciplinary Scientific GeoConference SGEM 2016, SGEM 2016 Conference Proceedings, Albena, Bulgaria, 30 June-6 July 2016; Volume 3, pp. 851-858.

67. Loska, A.; Paszkowski, W. SmartMaintenance-The Concept of Supporting the Exploitation Decision-Making Process in the Selected Technical Network System. In Intelligent Systems in Production Engineering and Maintenance (ISPEM 2017); Advances in Intelligent Systems and Computing; Springer International Publishing: Cham, Switzerland, 2018; Volume 637, pp. 64-73. [CrossRef]

(C) 2020 by the authors. Licensee MDPI, Basel, Switzerland. This article is an open access article distributed under the terms and conditions of the Creative Commons Attribution (CC BY) license (http://creativecommons.org/licenses/by/4.0/). 